\title{
Late Pennsylvanian fish assemblage from the Robledo Mountains and new records of Paleozoic chondrichthyans in New Mexico, USA
}

\author{
Alexander O. Ivanov \& Spencer G. Lucas
}

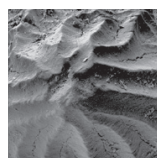

\begin{abstract}
We describe a very diverse and rich assemblage of fossil fishes from the Upper Pennsylvanian (Missourian) interval of the Horquilla Formation in the Robledo Mountains of southern New Mexico, USA. The assemblage includes bransonelliforms, symmoriiforms, a ctenacanthiform, a jalodontid, euselachians, neoselachians, an orodontiform, a helodontiform, an eugeneodontiform, a petalodontiform, a psephodontid, an acanthodian and actinopterygians. For the first time, the vascularization system of the teeth of Adamantina, Bransonella, Helodus and Agassizodus has been studied using a micro-CT. Besides the diverse fish assemblage from the Robledo Mountains, some other new records of Paleozoic chondrichthyans in New Mexico are documented. - Key words: fishes, Late Devonian-early Permian, New Mexico.
\end{abstract}

Ivanov, A.O. \& Lucas, S.G. 2019. Late Pennsylvanian fish assemblage from the Robledo Mountains and new records of Paleozoic chondrichthyans in New Mexico, USA. Bulletin of Geosciences 94(2), 235-255 (11 figures, 1 table). Czech Geological Survey, Prague. ISSN 1214-1119. Manuscript received January 1, 2019; accepted in revised form April 4, 2019; published online May 10, 2019; issued June 17, 2019.

Alexander O. Ivanov, Department of Sedimentary Geology, Institute of Earth Sciences, St. Petersburg State University, 29, 16 Line, St. Petersburg, 199178, Russia \& Institute of Geology and Petroleum Technology, Kazan Federal University, Kremlevskaya St. 4/5, Kazan, Russia; IvanovA-Paleo@yandex.ru・Spencer G. Lucas, New Mexico Museum of Natural History and Science, 1801 Mountain Road N.W, Albuquerque, NM 87104, USA

Fossils of fishes are known from Pennsylvanian strata at several localities across New Mexico, USA (Zidek \& Kietzke 1993; Lucas \& Estep 2000; Ivanov et al. 2009; Lucas et al. 2011; Hodnett \& Lucas 2015, 2017; Itano \& Lucas 2018). But, despite extensive field study, extremely diverse assemblages of fossil fishes with numerous isolated micro- and rare macroremains have proven to be elusive. This has been changed by the discovery of fish fossils in a conglomerate bed (so called "shark bed") of the Horquilla Formation in the Robledo Mountains of Doña Ana County, southern New Mexico, USA (Fig. 1).

The chondrichthyan remains here described from this bed are isolated teeth of bransonelliforms, symmoriiforms, a ctenacanthiform, a jalodontid, a euselachian, indeterminate protacrodontid and hybodontiform, anachronistid neoselachians, an orodontiform, a helodontiform, a eugeneodontiform, indeterminate petalodontiform, psephodontid and euchondrocephalian; as well as the buccopharyngeal denticles of symmoriiforms; and scales of various types. Rare acanthodian scales, and several actinopterygian teeth and scales also occur in this assemblage.

Besides the diverse fish assemblage from the Horquilla Formation of the Robledo Mountains, some new records of Paleozoic chondrichthyans in New Mexico that were not included in recent reviews (Hodnett \& Lucas 2015, 2017) are also documented here. These new occurrences increase the taxonomic diversity in the fish assemblages, and represent some taxa that are recorded in New Mexico for the first time: the fin spine of Ctenacanthus in the Upper Devonian and the teeth of Bransonella and Sphenacanthus in the Middle Pennsylvanian.

\section{Geological context}

The Robledo Mountains are an isolated fault-block mountain range northwest of Las Cruces in southern New Mexico, USA (Fig. 1). Most of the strata exposed in the Robledo Mountains belong to the lower Permian Hueco Group (Lucas et al. 2015). However, on the northern tip of the range, below its summit at Robledo Mountain, an $\sim 300 \mathrm{~m}$ thick section of Pennsylvanian marine strata of the Horquilla Formation is exposed (Krainer et al. 2015). Krainer et al. (2015) divided this section of the Horquilla Formation into five informal members (A-E, in ascending order) and documented fusulinids and conodonts that indicate the section ranges 
in age from Early Pennsylvanian (Morrowan) to early Permian (Wolfcampian). Member B is $\sim 24 \mathrm{~m}$ thick and consists of shallowing upward cycles of shale-limestone (Fig. 2). Near the top of member B is a $0.1 \mathrm{~m}$-thick bed of conglomerate composed of limestone and chert clasts. This conglomerate is crossbedded, clast supported, and its clasts are subrounded to subangular and up to $5 \mathrm{~cm}$ in diameter. It contains the fish fossils documented here at NMMNH locality 12253. Conodonts from the conglomerate represent the Idiognathodus cancellosus conodont Zone, of early Missourian (early Kasimovian) age (Rosscoe \& Barrick 2013, Barrick et al. 2013, Krainer et al. 2015).

\section{Material and methods}

Acetic acid was utilized to recover vertebrate microand rare macroremains from the samples of carbonatecemented rocks. The microremains were microphotographed using the scanning electron microscopes Hitachi S-3400N, Cambridge CamScan-4 and Tescan VEGA-II $\mathrm{XMU}$. The internal structure of some teeth was scanned with a SkyScan 1172 Bruker-microCT (Centre for X-ray Diffraction Studies of Research Park of the St. Petersburg State University) at a voltage of 55-96 kV and 104-167 $\mathrm{mA}$, with an aluminium/copper or aluminium filter and a $180^{\circ}$ rotation at the highest camera resolution with an average rotation step of $0.4^{\circ}$. The virtual cross-section images were generated from the $3 \mathrm{D}$ reconstruction using the software DataViewer, CTVox, and CTAn. The transparent mode of skeletal tissues was used for the reconstruction of the canal system.

The specimens described here are deposited in the collections of the New Mexico Museum of Natural History and Science, under specimens numbers NMMNH P-72263-72341.

\section{Fish assemblage from the Robledo Mountains}

The assemblage includes diverse isolated teeth, tooth plates and scales (Figs 3-10) of chondrichthyans, rare scales of acanthodians, and actinopterygian microremains such as teeth, scales and fragments of skull bone. The preservation of fish microremains from the Horquilla Formation of the Robledo Mountains is variable, but most of the fossils are incomplete, and broken parts sometimes have abraded surfaces of differing degrees. Some groups of fishes such as petalodontiforms, orodontiforms, eugeneodontiforms, and actinopterygians, are represented by very fragmentary remains that mainly are parts of tooth crowns. The sections (Fig. 5O) and micro-CT images

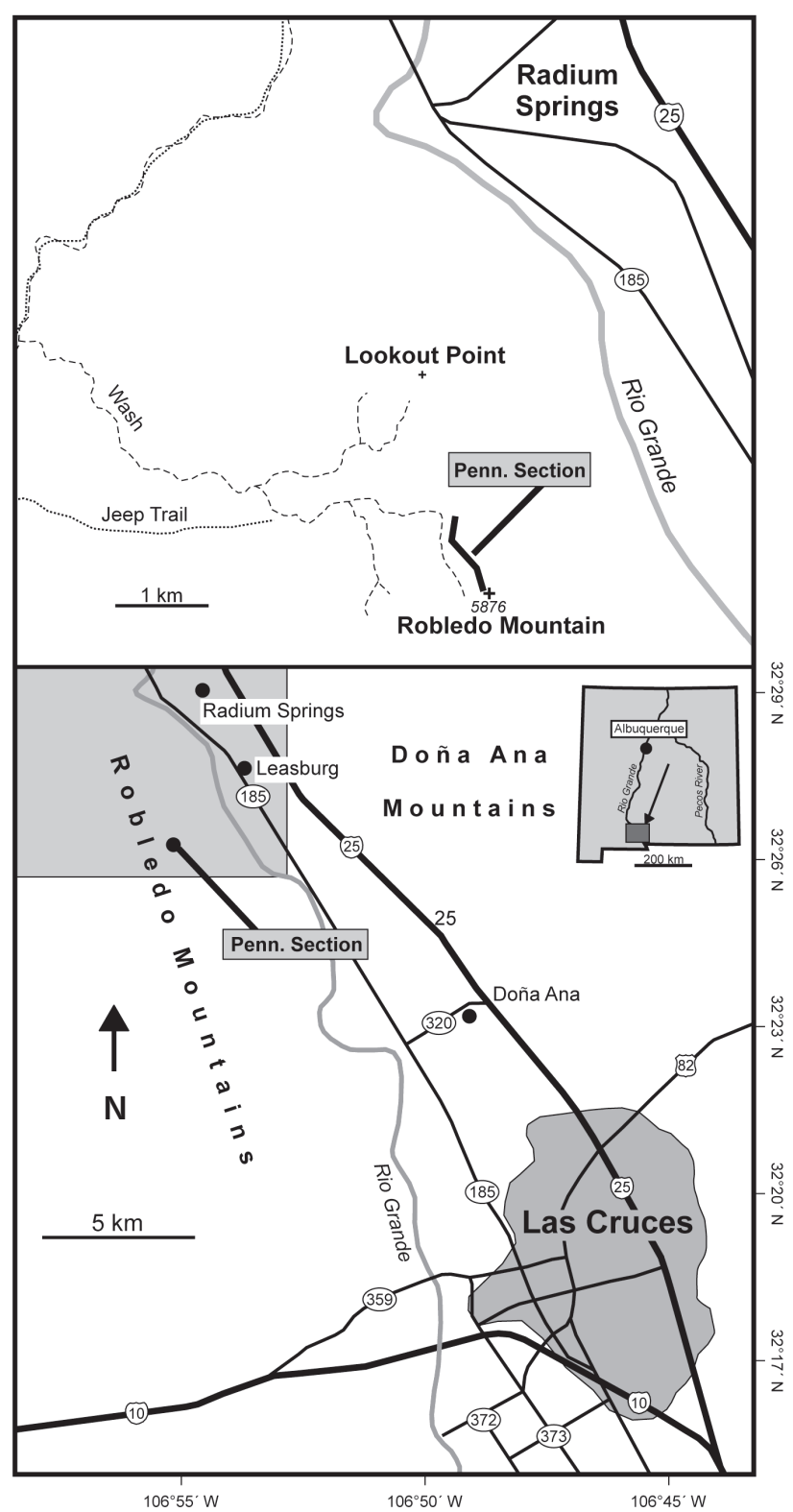

Figure 1. Index maps showing the location of the Pennsylvanian (Penn.) section on the northern end of the Robledo Mountains, New Mexico, USA. Modified from Krainer et al. (2015).

(Figs 3L, M; 5P, Q) demonstrate the presence of fracture recrystallization of skeletal minerals and secondary deposition in the vascular canals. Some remains bear traces of bioerosion. A few specimens (for example, some teeth of Adamantina and Helodus, Figs 5E-H, 8E-K) are complete, with well preserved skeletal tissue.

\section{Chondrichthyans}

A list of chondrichthyan taxa from the Horquilla Formation in the Robledo Mountains shows Tab. 1. 
Tab 1. Chondrichthyan taxa from the Horquilla Formation in the Robledo Mountains.

Class Chondrichthyes Huxley, 1880

Subclass: Elasmobranchii Bonaparte, 1838

Superorder Xenacanthimorpha Nelson, 1976

Order Bransonelliformes Hampe \& Ivanov, 2007

Family indet.

Genus Bransonella Harlton, 1933

Bransonella lingulata Ivanov \& Ginter, 1996

Bransonella nebraskensis (Johnson, 1984)

Superorder Cladodontomorphi Ginter, Hampe \& Duffin, 2010

Order Symmoriiformes Zangerl, 1981

Family Symmoriidae Dean, 1909

Genus Stethacanthus Newberry, 1889

$$
\text { Stethacanthus sp. }
$$

Family Falcatidae Zangerl, 1990

Genus Denaea Pruvost, 1922

Denaea sp.

Symmoriiformes indet.

Order Ctenacanthiformes Glikman, 1964

Family Heslerodidae Maisey 2010

Genus Glikmanius Ginter, Ivanov \& Lebedev, 2005

Glikmanius sp.

Elasmobranchii incertae sedis

Order indet.

Family Jalodontidae Ginter, Hairapetian \& Klug 2002

Genus Adamantina Bendix-Almgreen, 1993 Adamantina foliacea Ivanov, 1999

Cohort Euselachii Hay, 1902

Superfamily Protacrodontoidea Zangerl, 1981

Family Protacrodontidae Cappetta, Duffin \& Zidek, 1993

Genus Protacrodus Jaekel, 1925

Protacrodus sp.

Protacrodontidae indet

Order Hybodontiformes Maisey, 1975

Hybodontiformes indet.

Euselachii indet.

Subcohort: Neoselachii Compagno, 1977

Division Neoselachii Compagno, 1977

Order indet.

Family Anachronistidae Duffin \& Ward, 1983

Genus Cooleyella Gunnell, 1933

Coolevella amazonensis Duffin, Richter \& Neis, 1996

Cooleyella cf. fordi (Duffin \& Ward, 1983)

Cooleyella $\mathrm{sp}$.

Subclass Euchondrocephali Lund \& Grogan, 1997

Infraclass Paraselachii Grogan \& Lund, 2000

Order Orodontiformes Zangerl, 1981

Family Orodontidae De Konnick, 1878 Orodus sp.

Order Eugeneodontiformes Zangerl, 1981

Superfamily Edestoidea Hay, 1929

Family Agassizodontidae Zangerl, 1981

Genus Agassizodus St. John \& Worthen, 1875

Agassizodus sp.

Eugeneodontiformes indet.

Order Petalodontiformes Zangerl, 198

Petalodontiformes indet.

Superorder Holocephali Bonaparte, 1832-1841

Order Helodontiformes Patterson, 1965

Family Helodontidae Patterson, 1965

Genus Helodus Agassiz, 1838

Helodus sp.

Order Cochliodontiformes Obruchev, 1953

Family Psephodontidae Zangerl, 1981

Psephodontidae indet.

Euchondrocephali indet.

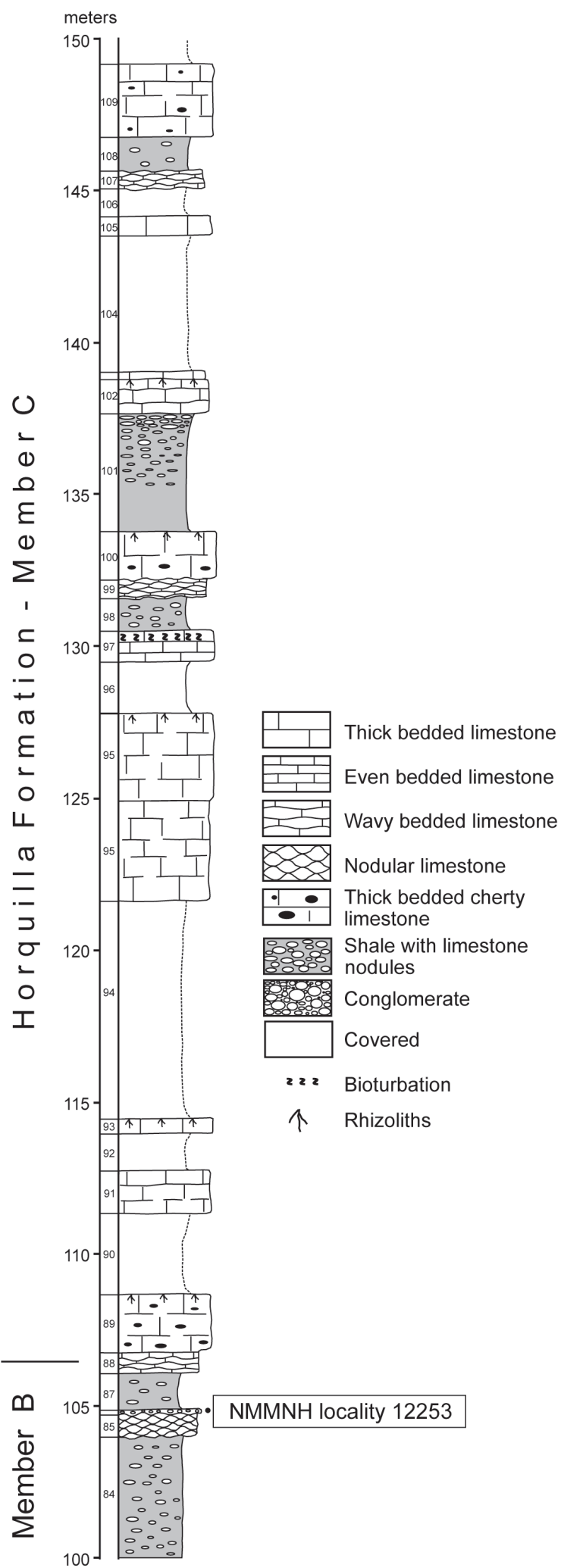

Figure 2. Part of the Pennsylvanian stratigraphic section at Robledo Mountain showing the location (bed 86) of NMMNH locality 12253, from which the fossil fishes reported here were collected. Modified from Krainer et al. (2015), where the complete Pennsylvanian section is illustrated. 


\section{Bransonelliforms}

The assemblage contains numerous isolated teeth of Bransonella, among them 64 teeth of B. lingulata Ivanov \& Ginter, 1996 and 6 teeth of B. nebraskensis (Johnson, 1984). The bransonelliform teeth of both species are incomplete (Fig. 3), with poorly preserved dental tissue, and secondary deposition into the vascular canals and fractures (Fig. 3L, M).

The teeth of Bransonella lingulata Ivanov \& Ginter, 1996 (Fig. 3A-M) possess a tricuspid, diplodont crown with higher and wider lateral cusps than the central one. The

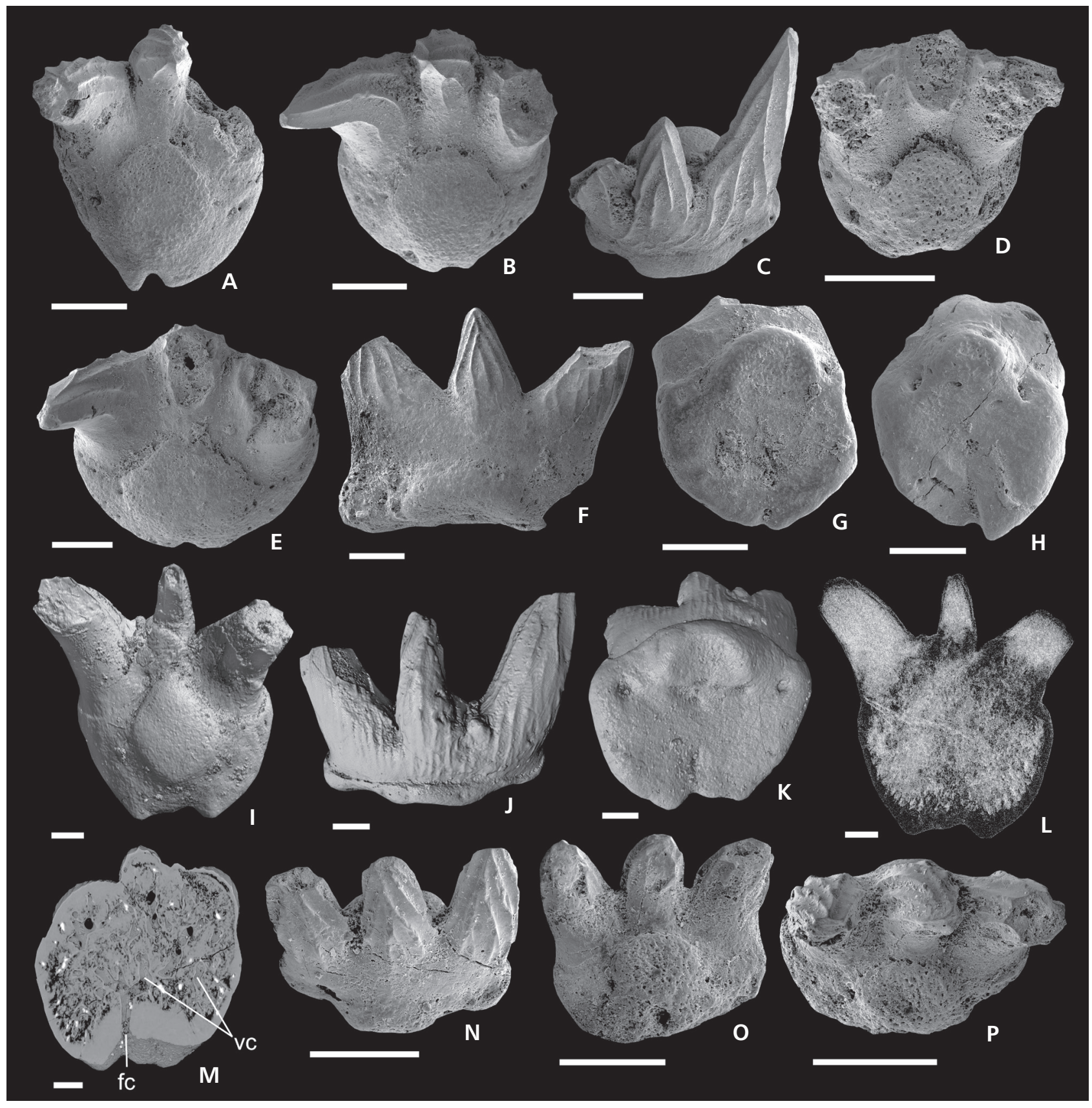

Figure 3. Teeth of the xenacanthimorph Bransonella, Robledo Mountains, New Mexico, USA; Horquilla Formation, Missourian, Upper Pennsylvanian (A-H, N-P - scanning electron micrographs; I-M - micro-CT images). A-M - Bransonella lingulata Ivanov \& Ginter, 1996; A - NMMNH P-72263, occlusal view; B, C - NMMNH P-72264, occlusal (B) and labial (C) views; D - NMMNH P-72265, occlusal view; E - NMMNH P-72266, occlusal view; F - NMMNH P-72267, labial view; G - NMMNH P-72268, basal view; H - NMMNH P-72269, basal view; I-M - NMMNH P-72270, oblique occlusal (I), labial $(\mathrm{J})$ and basal $(\mathrm{K})$ views, view with transparent dental tissue $(\mathrm{L})$ and virtual section of tooth base $(\mathrm{M}) \cdot \bullet \mathrm{N}-\mathrm{P}-$ Bransonella nebraskensis (Johnson, 1984), NMMNH P-72271, labial (N), lingual (O) and occlusal (P) views. Scale bars $=0.3 \mathrm{~mm}$. Abbreviations: $\mathrm{fc}-$ foramen of vascular canal; vc - vascular canal. 


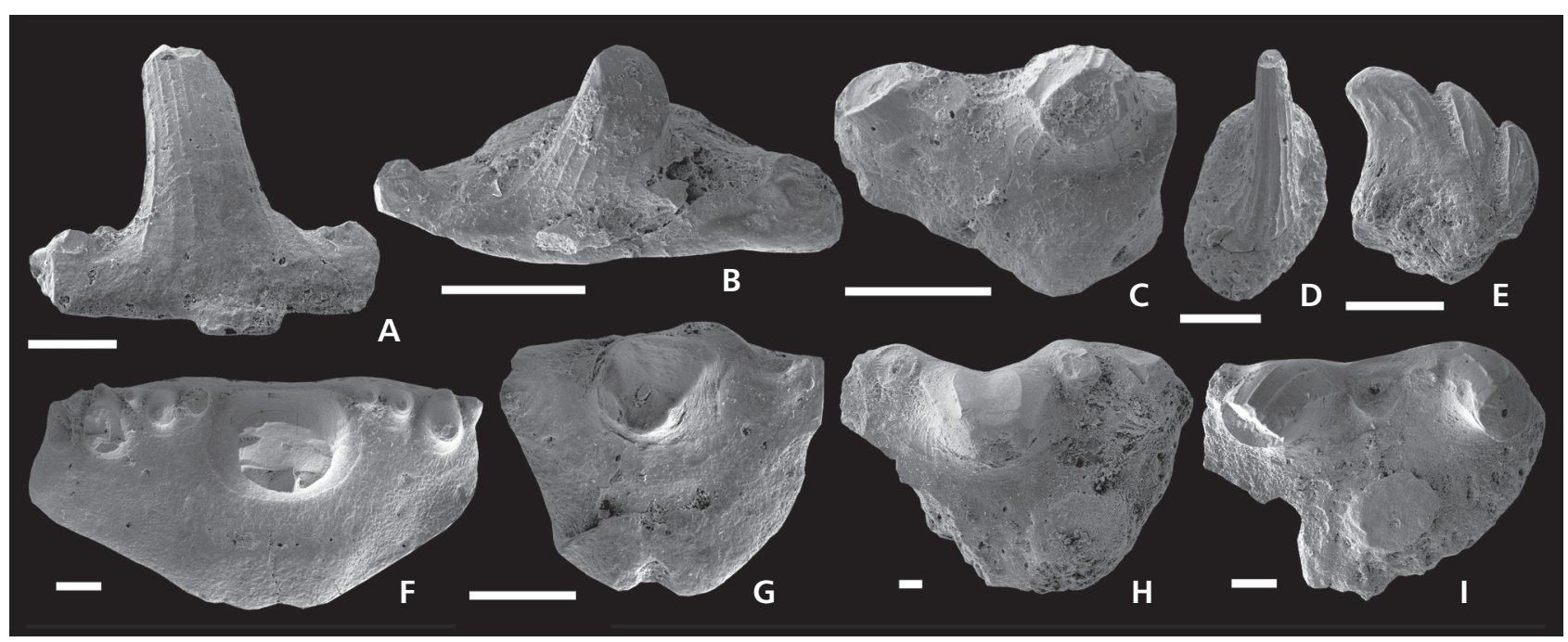

Figure 4. Microremains of symmoriiforms (A-G) and ctenacanthiforms (H, I), Robledo Mountains, New Mexico, USA; Horquilla Formation, Missourian, Upper Pennsylvanian. - A-C - teeth of Denaea sp.; A - NMMNH P-72272, labial view; B - NMMNH P-72273, oblique labial view; C - NMMNH P-72274, occlusal view. D - symmoriiform monocuspid denticle, NMMNH P-72278, crown view. $\bullet$ E - symmoriiform buccopharyngeal denticle ("Stemmatias" type), NMMNH P-72277, lateral view. • F, G - teeth of Stethacanthus sp., occlusal views: F - NMMNH P-72275; G - NMMNH P-72276. • H, I - teeth of Glikmanius sp., occlusal views; H - NMMNH P-72279; I - NMMNH P-72280. Scale bars $=0.2 \mathrm{~mm}$.

lateral cusps are almost round in cross section, but the central cusp is compressed mesio-distally. The well preserved cusps are acuminate and bear an inverted "V"-nested ornamentation on the labial side and a straight crista on the lingual side. The labial ornamentation can reach the crown/ base boundary (Fig. 3C, J) but sometimes the cristae cover only the upper part of the crown (Fig. 3F). One tooth bears a tiny intermediate cusplet between the central and lateral cusps (Fig. 3J). The lingually extended tooth bases range from oval to circular in shape, and vary in width. The base possesses a prominent apical button occupying almost the entire occlusal surface and a semilunar labiobasal tubercle at the labial rim. The apical button varies from oval to round in shape. The width of the button and of the labio-basal tubercle corresponds to the width and shape of the base. The foramen of the main vascular canal perforates the linguo-basal part of the base, forming a distinct notch at the lingual rim. The small foramina of the secondary vascular canals surround the apical button (Fig. 3D, E). Two foramina of the lateral canals open on both sides of the labio-basal tubercle (Fig. $3 \mathrm{H}, \mathrm{K}$ ).

The teeth of Bransonella nebraskensis (Johnson, 1984) (Fig. 3N-P) have a tricuspid crown with a central cusp that is just a little shorter then the lateral ones. All cusps are rounded in cross section and the same size at the crown/base junction. The inverted "V"-nested ornamentation of the cusps is slightly twisted. The oval tooth base bears a prominent, circular apical button that does not reach the lingual rim (Fig. 30). The foramen of the main vascular canal opens between the button and the lingual rim. The distinct labio-basal tubercle is semilunar and does not extend labially (Fig. 3N).

\section{Symmoriiforms}

The symmoriiform remains include 24 isolated, fragmentary teeth of Denaea sp., four isolated, incomplete teeth of Stethacanthus sp., and several denticles. The poorly preserved teeth of Denaea (Fig. 4A-C) possess the cladodont crown with high central and moderate lateral cusps. The intermediate cusplets are not preserved. The cusps are round in cross section. The central cusp is lingually inclined, slightly incurved and covered by straight tiny cristae on both the labial and the lingual sides. The tooth base is triangular in shape, with a pointed part of the lingual rim. The distinct, rounded apical button is located at the lingual rim. The labio-basal tubercle is prominent, oval in shape, and extends mesio-distally.

The incomplete teeth of Stethacanthus sp. (Fig. 4F, G) have a crown consisting of a large central cusp and nine small cusps and cusplets. The central cusp is compressed labio-lingually, and the other cusps are round in cross section. One pair of cusps is higher and wider then the other intermediate ones. One accessory cusplet is placed labial to the line of cusps. The cusp ornamentation is not preserved. The tooth base is subtriangular in shape, with an extended lateral part that is prominent on the labial edge of the lateral parts of the crown. The large apical button is rectangular in outline, located at the lingual rim and separated from the central cusp by a shallow depression.

The symmoriiform denticles contain the monocuspid (Fig. 4D) and multicuspid, spiral-like (Fig. 4E) denticles. The first one has a high, conical cusp flattened laterally, inclined posteriorly and covered by straight cristae. The prominent denticle base is oval in shape, with a prominent 
basal side. Such denticles belong to denticles from the spine-brush complex of some symmoriiforms (e.g., Coates \& Sequeira 2001). The multicuspid denticles (Fig. 4E) have three to five recurved, elongate cusps consecutively overlapping each other. The cusps bear coarse cristae. The base is extended basally and anteriorly. These denticles are buccopharyngeal or mucous membrane denticles (Zangerl \& Case 1976, Williams 1985, Coates \& Sequeira 2001), and were described as the formal taxon "Stemmatias (Stemmatodus)" (St. John \& Worthen 1875).

\section{Ctenacanthiformes}

Six isolated teeth of the ctenacanthiform Glikmanius (Fig. $4 \mathrm{H}, \mathrm{I})$ are fragmentary and poorly preserved. They possess cladodont crowns with large central and moderate-sized lateral cusps separated by one or two small intermediate cusps. The main cusps are compressed labio-lingually, and bear a few distinct, straight cristae. The tooth base is semicircular in shape, elongated mesiodistally, and extended lingually. Two rounded apical buttons are located at a considerable distance from each other on the occlusal side of the base. The deep labial depression is separated by two oval, labio-basal tubercles.

\section{Jalodontids}

The jalodontid remains include 56 isolated teeth and tooth fragments of Adamantina foliacea Ivanov, 1999 in varying preservation (Fig. 5). The teeth possess a crown consisting of three to five cusps and a lingually extended base. The cusps are wide, triangular in shape, slightly labio-lingually compressed and inclined lingually. They bear strong, lanceolate ornamentation on the labial side and rare, straight cristae on the lingual side. There are two or three lanceolate ridges. The short, straight or incurved additional ridges are placed inside the lanceolate ridges. The cusps in the tricuspid crown are equal in height and fused in their basal part (Fig. 5A-F). The upper parts of the lateral cusps can diverge from the central cusp. The crown with four cusps has three almost equal cusps and an accessory lateral cusp, sometimes inclined mesially or distally. This lateral cusp can be tiny (Fig. 5H, J) or moderate in size but lower than the main cusps (Fig. $5 \mathrm{~K}-\mathrm{M}$ ). The lanceolate ridges on such crowns are common in main and accessory lateral cusps, and one ridge is traced on both cusps (Fig. 5K, L). The five-cusped crown has a high central, moderate intermediate and small lateral cusps forming a fan-shaped structure (Fig. $5 \mathrm{~N}$ ). The intermediate cusps are shorter than the central one but they have the same width. The cusps in a five-cusped crown are separated by deep notches. The crown/base junction is poorly developed in tricuspid teeth, and narrow in multicuspid ones.
The tooth base is thick, with smooth, convex occlusal and slightly concave basal surfaces, and is arched, especially in tricuspid teeth. Two labio-basal tubercles are prominent, round or oval, and separated from each other by a wide depression (Fig. 5E, K). Their shape and size, as well as the distance between them vary: the circular tubercles can be placed far apart (Fig. 5A-G), or the oval tubercles are nearly in contact with each other (Fig. 5H-J). The large foramina of the main vascular canal penetrate the occlusal surface, at the lingual rim (Fig. 5D, F) and in the concave part of the basal side (Fig. 5A, G). The numerous tiny foramina open in the shallow groove on the occlusal side, near the crown/base junction.

The vascularization system of the Adamantina teeth contains the main, secondary and pulp canals (Fig. 5O-Q). The large main canal passes across the tooth base, from the lingual rim to the labial depression. The numerous short and narrow secondary canals are branched from the main one, and extended on the new branch. Two long canals open on the outside of the basal tubercles. The pulp canals are very wide and their width does not change on almost the entire height of the cusp (Fig. 5O).

\section{Euselachians}

The assemblage contains the isolated teeth of protacrodontids, hybodontiforms and an undetermined euselachian. Protacrodontid remains are represented by nine incomplete teeth of Protacrodus sp. and 16 fragmentary teeth of an undetermined protacrodontid. They mainly include fragments of the tooth crown. The teeth of Protacrodus (Fig. 6A-F) possess a pyramidal crown that is labio-lingually compressed. The cusps are gradually arranged by their height, fused basally, often inclined mesially or distally, and covered by coarse cristae. The cristae diverge from the cusp apex, and are wavy and bifurcate. The accessory cusplets may occur between lateral cusps (Fig. 6C). The base is slightly lingually extended and arched. The rows of canal foramina occur on the labial and occlusal sides. Most of the Protacrodus teeth have two to four pairs of lateral cusps, and a wide central cusp that is slightly higher than the lateral ones (Fig. 6A-C, F). These teeth are very similar to the teeth of Protacrodus vetustus Jaekel, 1925 (e.g., Ginter et al. 2010). But, several teeth possess a very high and wide central cusp, and only one pair of small lateral cusps (Fig. 6D, E). Such teeth resemble the tooth morphotype 1 of Protacrodus serra Ginter, Hairapetian \& Klug, 2002 (Ginter et al. 2002, text-fig. 11a-e, pl. 11, fig. a).

The incomplete teeth of an undetermined protacrodontid (Fig. 6G-J) have a monolithic, slightly pyramidal crown with an occlusal crest. Coarse ridges diverge from the crest on the labial and lingual sides of the crown. The ridges on the labial side are terminated in the prominent 


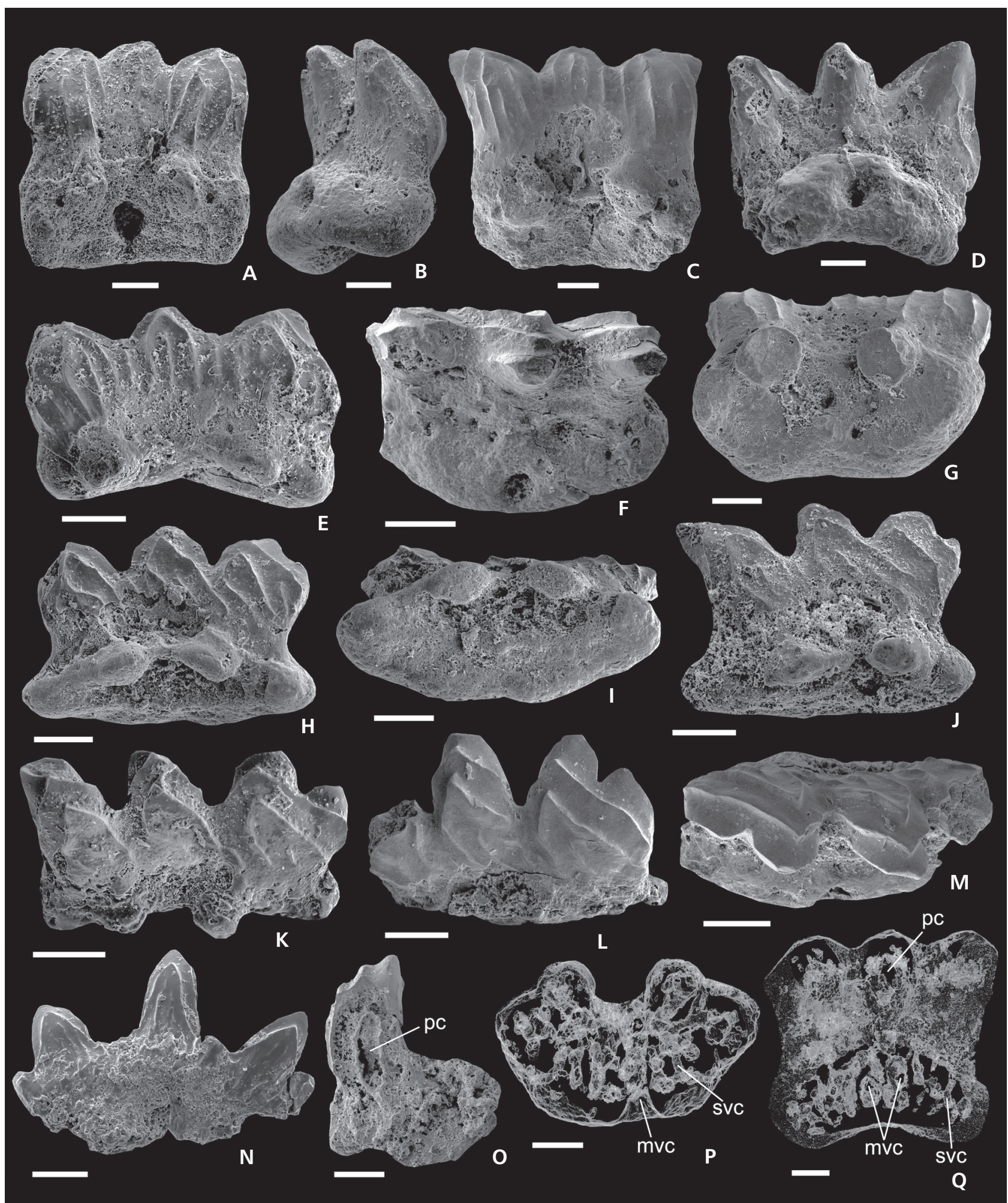

Figure 5. Teeth of the jalodontid Adamantina foliacea Ivanov, 1999; Robledo Mountains, New Mexico, USA; Horquilla Formation, Missourian, Upper Pennsylvanian (A-O - scanning electron micrographs; P, Q - micro-CT images in transparent model); A - NMMNH P-72302, oblique labial view; B, P, Q - NMMNH P-72303, lateral view (B), virtual sections of base (P) and tooth in lingual view (Q); C - NMMNH P-72304, oblique labial view; D - NMMNH P-72305, lingual view; E - NMMNH P-72306, labial view; F - NMMNH P-72307, occlusal view; G - NMMNH P-72308, basal view; H, I - NMMNH P-72309, labial (H) and basal (I) views; J - NMMNH P-72310, labial view; K - NMMNH P-72311, labial view; L, M, NMMNH P-72312, labial (L) and occlusal (M) views; N - NMMNH P-72313, labial view; O - transversal cross-section of tooth, NMMNH P-72314. Scale bars $=0.1 \mathrm{~mm}$. Abbreviations: mvc - main vascular canal; $\mathrm{pc}-$ pulp canal; svc - secondary vascular canal. 
projection separated by deep notches (Fig. 6G, H). These projections become wider in the direction of the crown center (Fig. 6G). The tooth base is extended lingually and perforated by large foramina on the occlusal surface (Fig. 6G, I). These teeth resemble the teeth of Deihim mansureae Ginter, Hairapetian \& Klug, 2002 from Iran and Armenia (Ginter et al. 2010), from Australia (Roelofs et al. $2015,2016)$, and especially the teeth of that species from New Mexico (Ivanov \& Lucas 2011). But the tooth crown of Deihim is pyramidal with prominent cusps and without an occlusal crest, but bears the distinct labial cusplets unrelated to the crown ornamentation. These protacrodontid teeth described here probably belong to a new genus.

Two isolated tooth crowns of an undetermined hybodontiform (Fig. $6 \mathrm{~N}$ ) possess a triangular central cusp, prominent labial peg and ridges on the labial and lingual sides. The ridges are extended basally and form the projections separated by depressions. The short ridges occur on the labial peg. These tooth crowns resemble some Paleozoic lonchidiid teeth attributed to "Lissodus" sp. (e.g., Duncan 2004, Ivanov \& Lebedev 2014). However, lonchidiid teeth possess a well-developed occlusal crest and extended labial peg.

The isolated tooth of a peculiar undetermined euselachian (Fig. 6K-M) has a tricuspid smooth crown with large, triangular central and small, rounded lateral cusps. The crown is compressed labio-lingually and partly separated from the base by a shallow depression (Fig. 6L). The tooth base is considerably extended lingually and slightly labially (Fig. 6M), with a sloped lingual part. The large foramina of the vascular canals perforate the lingual and basal surfaces.

\section{Neoselachians}

The neoselachians are represented by teeth of the anachronistids Cooleyella amazonensis Duffin, Richter \& Neis, 1996, Cooleyella cf. fordi (Duffin \& Ward, 1983) and Cooleyella sp. The assemblage contains 20 isolated teeth and tooth fragments of $C$. amazonensis Duffin, Richter \& Neis, 1996 (Fig. 7A-E). These small teeth possess a smooth crown that is wider than the base. The crown bears a distinct occlusal crest separating the trapezoidal, sloping labial and short, almost vertical lingual faces (Fig. 7E). The small to moderate central cusp is placed on the crest. The crown has a short and wide labial flange, and rounded lateral blades (Fig. 7A, C). The crown/ base junction is deep, and the crown overhangs the base laterally and labially. The narrow tooth base is semilunar in shape, with extended, convex lingual and very narrow labial surfaces (Fig. 7D). The rounded lingual edge is perforated by the foramen of the main vascular canal. The convex basal surface bears a small, round basal tubercle and an oval pit of the pulp cavity (Fig. 7D).
The microremains of Cooleyella cf. fordi (Duffin \& Ward, 1983) include 14 isolated teeth and tooth fragments (Fig. 7H-M). These teeth are extended mesio-distally, and have a crown narrower than the base. The crown has three cusps separated by depressions (Fig. 7I); long, sloping labial and short lingual faces; a long, almost triangular labial flange (Fig. 7K); accuminate lateral blades (Fig. $7 \mathrm{H}, \mathrm{K}$ ); and a discontinuous occlusal crest. The central cusp is prominent, larger than the lateral ones (Fig. 7I, J), and rounded in cross section. The crown/base junction is incised and narrow, with a distinct labial and lingual groove. The tooth base is oval in shape, considerably extended lingually and laterally, and has a convex lingual, very short labial and concave basal surfaces. The foramen of the main vascular canal is perforated along the lingual rim, often forming a small notch. A basal tubercle is oval in shape, and placed beneath the labial flange (Fig. 7I). The convex basal surface bears a large pit of the pulp cavity and a narrow depression surrounding the basal tubercle.

Five isolated teeth of Cooleyella sp. (Fig. 7F, G) possess the crown and base of the same size or the crown slightly wider than the base. The crown of some teeth is asymmetrical. The crown has a prominent central and small lateral cusps; tiny tubercle-like cusplets are placed between the cusps (Fig. 7F). The occlusal crest is poorly developed and discontinued by a narrow depression that surrounds the central cusp. The labial flange and lateral blades of the crown are accuminate (Fig. 7F). The crown/ base junction is rather narrow. The tooth base has a lingual extension and rounded basal tubercle. These teeth differ from the teeth of Cooleyella amazonensis Duffin, Richter \& Neis, 1996 in their long, accuminate labial flange, tubercle-like cusplets, and larger base with a wide basal tubercle; the teeth of Cooleyella cf. fordi (Duffin \& Ward, 1983) are distinguished from the teeth of Cooleyella sp. in the considerably shorter base; longer labial flange; and round shape of the basal tubercle.

\section{Euchondrocephalians}

The diverse euchondrocephalians (Figs 8, 9) include orodontiforms, helodontiforms, cochliodontiforms, eugeneodontiforms, petalodontiforms and unidentified euchondrocephalians. Most of the euchondrocephalian remains, such as those of petalodontiforms, orodontiforms, and eugeneodontiforms, are very fragmentary and include the incomplete tooth crowns; but some teeth are complete and well preserved. Two isolated and incomplete tooth crowns of an unidentified euchondrocephalian are present in the assemblage (Fig. 8L). They are considerably elongated mesio-distally, with prominent central and sloped lateral parts, and with a small, triangular lingual peg slightly dislocated from the central prominence. These tooth crowns are slightly similar to the crown of some Helodus, 


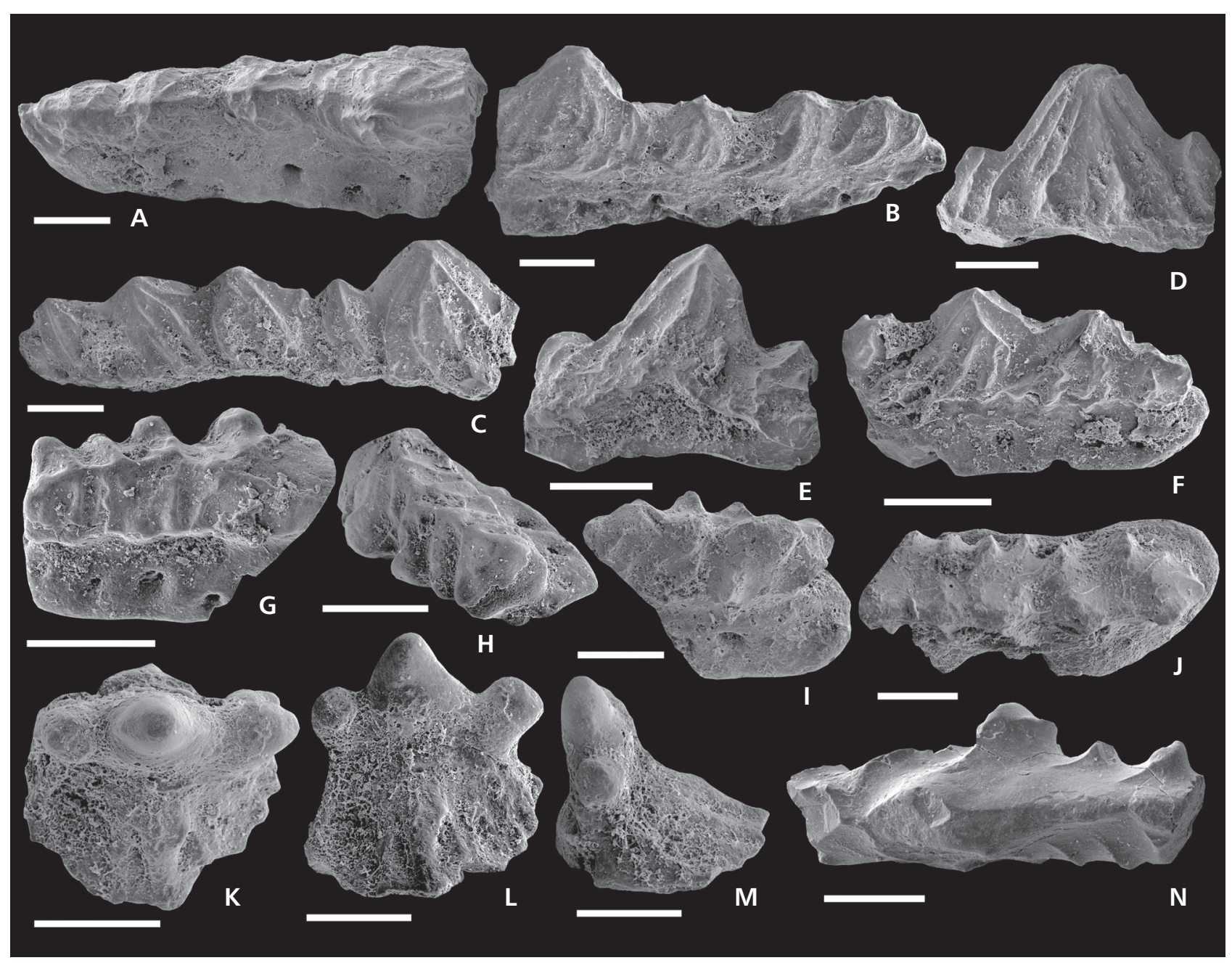

Figure 6. Teeth of euselachians; Robledo Mountains, New Mexico, USA; Horquilla Formation, Missourian, Upper Pennsylvanian. • A-F Protacrodus sp.; A, B - NMMNH P-72281, occlusal (A) and labial (B) views; C - NMMNH P-72282, tooth crown, labial view; D - NMMNH P-72283, tooth crown, labial view; E - NMMNH P-72284, labial view; F - NMMNH P-72285, labial view. • G-J - Protacrodontidae indet.; G, H NMMNH P-72286, oblique occlusal (G) and lateral (H) views; I - NMMNH P-72287, oblique occlusal view; J - NMMNH P-72288, occlusal view. • K-M - Euselachii indet., NMMNH P-72289, occlusal (K), lingual (L) and lateral (M) views. $\bullet \mathrm{N}-$ Hybodontiformes indet., NMMNH P-72288, tooth crown, occlusal view. Scale bars $=0.2 \mathrm{~mm}$.

Leiodus and Fadenia (Stahl 1999, Ginter et al. 2010), but the preservation of the teeth prevents their genus-level identification.

\section{Orodontiforms}

The microremains of Orodus sp. are represented by three isolated tooth crowns with only small fragments of the tooth base preserved (Fig. 8A-C). The tooth crown is pyramidal, elongated mesio-distally, with a prominent central cusp. The crown is covered by anastomosing, incurving coarse ridges, sometimes dividing on different levels. The ridges diverge from the tip of the central cusp. The central cusp is round in cross section, and separated from the remaining crown by narrow but shallow grooves. The teeth resemble some morphotypes of Orodus mammillaris
Newberry \& Worthen, 1866 from the Upper Devonian and Mississippian of the USA (Ginter et al. 2010).

\section{Helodontiforms}

The assemblage includes seven isolated teeth and tooth crowns of Helodus sp. (Fig. 8D-K). Some of the tooth crowns and teeth are very well preserved. The teeth possess a crown that is elongated mesio-distally, with a prominent central part, sloped mesial and distal parts, an extended, pointed labial peg, and large tubule openings on the occlusal surface. The small teeth have a weakly developed occlusal crest (Fig. 8D). The crown is wider than the tooth base, and overhangs the base on the labial side. The crown is separated from the base by a deep groove on the lingual and labial sides. This groove is not developed in 


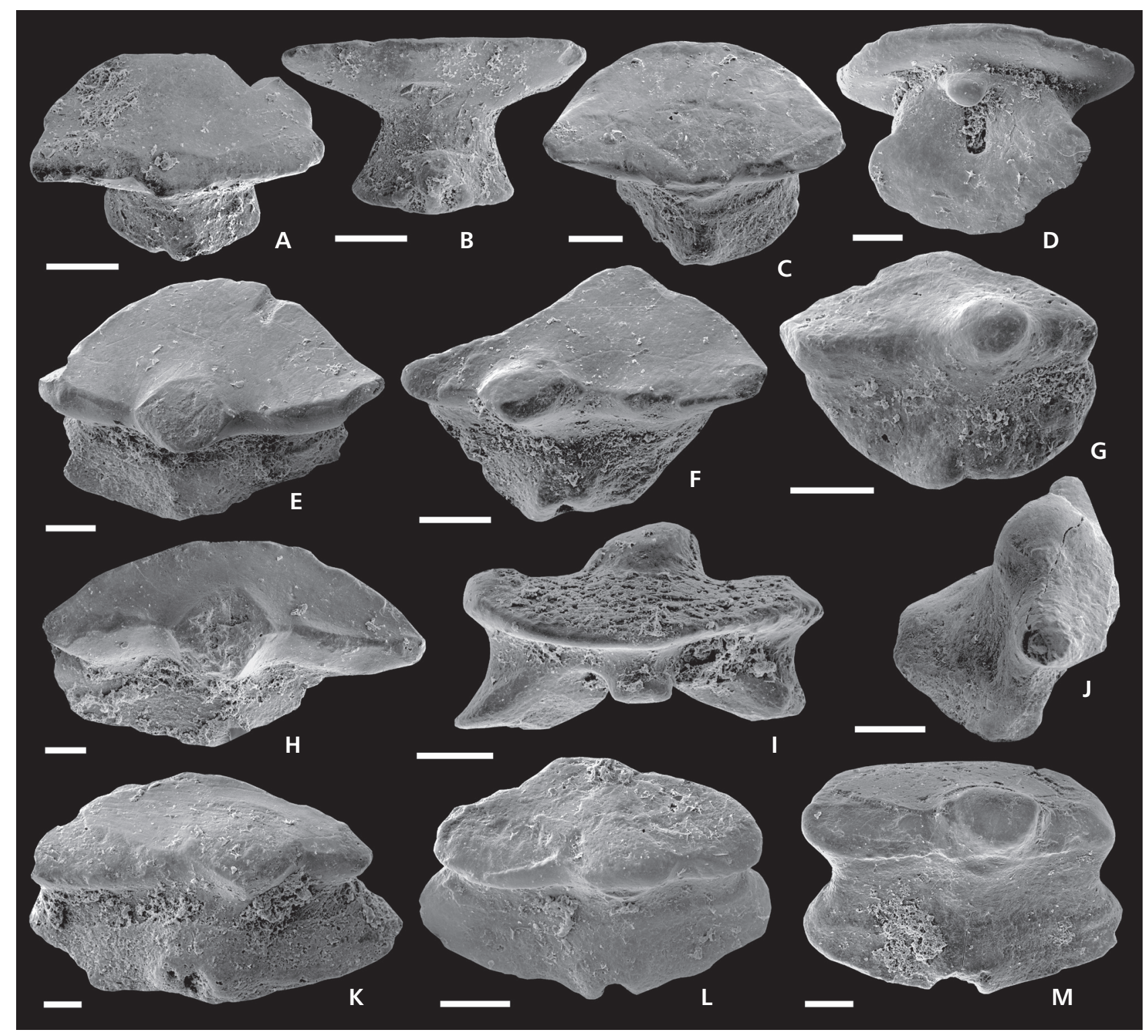

Figure 7. Teeth of the neoselachian Cooleyella; Robledo Mountains, New Mexico, USA; Horquilla Formation, Missourian, Upper Pennsylvanian. • A-E - Cooleyella amazonensis Duffin, Richter \& Neis, 1996; A, B - NMMNH P-72290, occlusal (A) and lingual (B) views; C - NMMNH P-72291, occlusal view; D - NMMNH P-72292, oblique labial view; E - NMMNH P-72293, occlusal view. • F, G - Cooleyella sp., occlusal views; F NMMNH P-72294; G - NMMNH P-72295. • H-M - Cooleyella cf. fordi (Duffin \& Ward, 1983); H - NMMNH P-72296, occlusal view; I - NMMNH P-72297, labial view; J - NMMNH P-72298, lateral view; K - NMMNH P-72299, occlusal view; L - NMMNH P-72300, occlusal view; M - NMMNH P-72301, oblique occlusal view. Scale bars $=0.1 \mathrm{~mm}$.

the lateral corners. The tooth base is extended lingually and arched, with slightly convex, ridged occlusal and almost flat basal surfaces. The base is perforated by numerous large foramina of vascular canals. They form rows on the lingual and labial sides. The tooth crown consists of the tubular dentine with a hypermineralized layer in the upper part and trabecular dentine in the basal part (Fig. 8H-K). The divided vertical vascular canals in the crown are surrounded by peritubular trabeculine. These canals rise into the hypermineralized layer of the crown (Fig. 8J). The lower part of the tooth base is composed of solid lamellar tissue. The wide and short basal vascular canals penetrate across the tooth base and branch in the lower part of the crown, connecting the vertical canals and weakly developed pulp cavity (Fig. 8I). The basal canals are connected with each other by short ramifications (Fig. 8K).

\section{Cochliodontiforms}

The cochliodontiform remains include five isolated incomplete tooth plates of unidentified psephodontids (Fig. $8 \mathrm{M})$. They are the poorly preserved, thick, central part of 


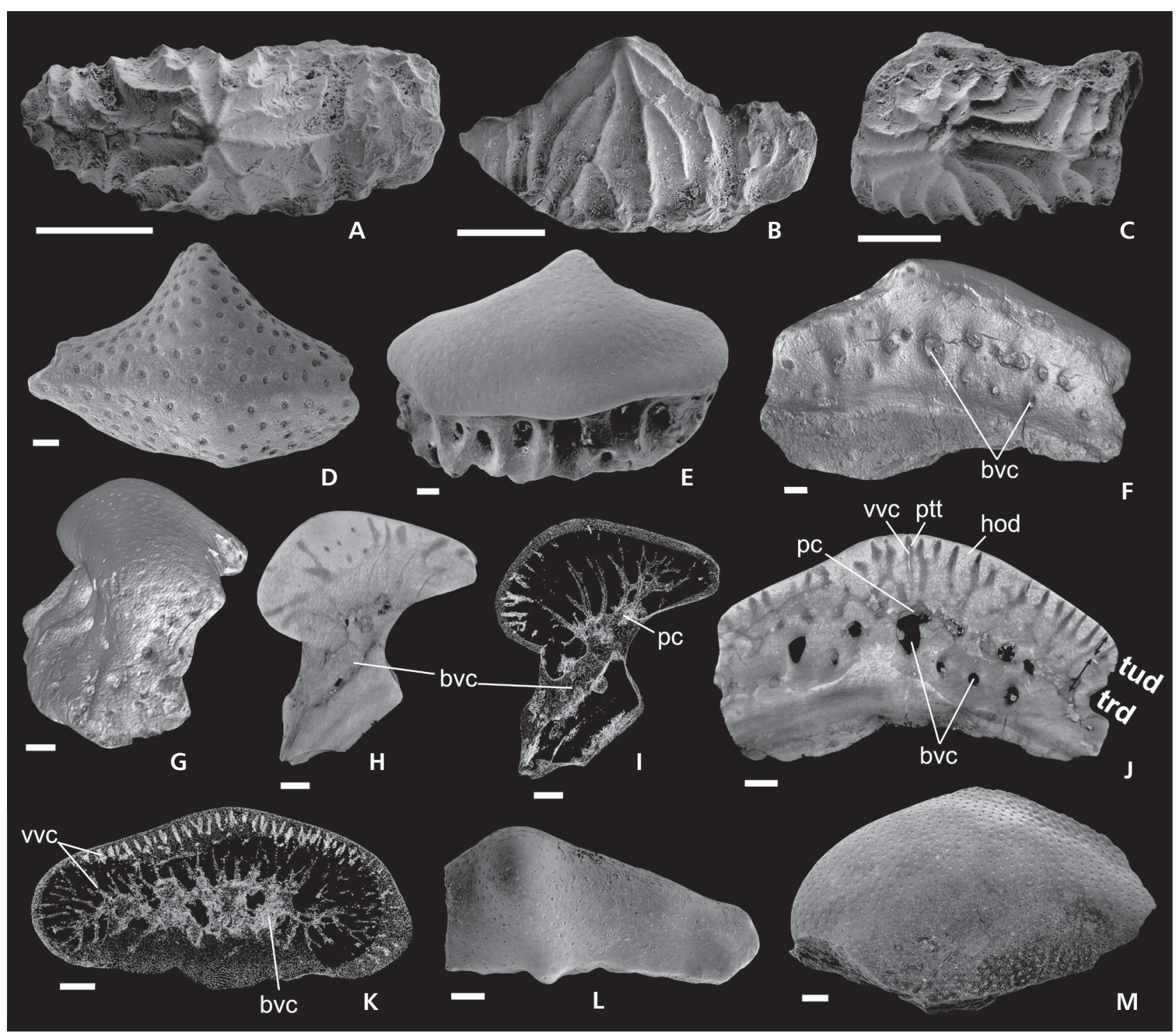

Figure 8. Euchondrocephalian teeth and tooth plate; Robledo Mountains, New Mexico, USA; Horquilla Formation, Missourian, Upper Pennsylvanian (A-E, L, M - scanning electron micrographs; F-K - micro-CT images). $\bullet A-C-$ Orodus sp., tooth crowns; A, B - NMMNH P-72315, occlusal (A) and labial (B) views; C - NMMNH P-72316, occlusal view. • D-K - Helodus sp.; D - NMMNH P-72317, tooth crown, occlusal view; E-K - NMMNH P-72318, tooth, oblique occlusal (E), labio-basal (F) and lateral (G) views, transverse (H, I in transparent mode) and sagittal (J) virtual sections of tooth, frontal virtual section of crown ( $\mathrm{K}$ in transparent mode). $\cdot \mathrm{L}-$ Euchondrocephali indet., NMMNH P-72319, tooth crown, occlusal view. • M - Psephodontidae indet., NMMNH P-72320, tooth plate, occlusal view. Scale bars $=0.5 \mathrm{~mm}$. Abbreviations: bvc - basal vascular canal; hod - hypermineralized orthodentine; pc - pulp cavity; ptt - peritubular trabeculine; trd - trabecular dentine; tud - tubular dentine; vvc - vertical vascular canal.

the tooth plate with broken edges. The preserved part of the tooth plates is arched, with a very prominent, hemispherical central part on the occlusal side, and concave on the basal side. Numerous small foramina penetrate the occlusal surface.

\section{Eugeneodontiforms}

The eugeneodontiforms are represented in the assemblage by 10 isolated crowns and fragments of Agassizodus lateral teeth, as well as two isolated tooth crowns of indetermin- ate eugeneodontiforms. The fragmentary teeth of Agassizodus sp. (Fig. 9A-H) possess the crown, which is strongly elongated mesio-distally and compressed labio-lingually. The crown bears a low central cusp (Fig. 9B), a wavy occlusal crest and long, serrated buttresses on the labial side (Fig. 9D, E). The ridges of differing lengths diverge from the occlusal crest on the labial and lingual sides: the long, serrated ridges - on the lingual side, from the central cusp and opposite of the buttress; the short ridges - on both the labial and lingual sides, between the buttresses and long ridges (Fig. 9B, D). The occlusal surface also bears small tubercles 
that often form a row (Fig. 9C, D). The crown is composed of tubular dentine with a hypermineralized orthodentine layer (Fig. 9F-H). The numerous thin vertical canals are surrounded by a tiny layer of peritubular trabeculine (Fig. 9H). They diverge from the basal canal and rarely branch.

The tooth crowns of an indeterminate eugeneodontiform (Fig. 9I-L) are very elongate mesio-distally, and possess a central swollen part, the labial buttresses and a distinct, wavy occlusal crest. The labial buttress is long in the central part and short in the lateral parts (Fig. 9I). The wavy ridges are placed on the labial buttress and opposite of the lingual side (Fig. 9I). The vertical vascular canals are divided and strongly diverged (Fig. 9J), and arranged in two parallel rows (Fig. 9K, L). These tooth crowns slightly resemble the teeth of Gilliodus (Ginter et al. 2010).

\section{Petalodontiforms}

Four isolated tooth fragments of unidentified petalodontiforms (Fig. 9M, N) are found in the assemblage. These poorly preserved fragments are a small part of the tooth crown near the cutting edge. One fragment is the top acuminated part with an abraded surface and visible vertical vascular canals (Fig. 9M). Other fragments are small pieces of the sloped part of the tooth crown with a sharp cutting edge and imbricated ridges (Fig. 9N).

\section{Chondrichychthyan scales}

The chondrichthyan scales in the assemblage include various morphotypes such as ctenacanthid, euselachian, protacrodontid and orodontid, as well as a tessera-like scale. The scales of ctenacanthid type (Fig. 10A-C) possess a polyodontode crown that is curved backward and serrated posteriorly. The crown consists of triangular central and long, narrow lateral odontodes arranged subparallel to each other and separated by narrow grooves. The odontodes are ornamented with thin ridges. The scale neck is narrow and shallow, or weakly developed. The base is oval or round in outline, with a concave basal side.

The tessera-like scales (Fig. 10D) have a low polyodontode crown and large oval base. The odontodes are triangular tubercles of different sizes, partly fused and form the compact crown. The base has flat external and convex basal surfaces. Similar scales are often determined as head scales (e.g., Burrow et al. 2009), and similar scales were described as those of Adamantina benedictae Bendix-Almgreen, 1993.

The numerous euselachian scales have a crown that ranges from low, drop-like (Fig. 10F) to high, elongate (Fig. 10E). The crown is inclined and pointed posteriorly, and bears strong ridges of different sizes. The scale neck is well developed, narrow and deep. The base has convex external and concave basal surfaces, and a serrated edge with projections of different length and small notches.

The scales of protacrodontid type possess a flat, low, monolithic, polyodontode crown, narrow neck and a prominent, hemispherical base slightly larger than the crown. These scales are represented by two morphotypes. The first one has a wide central part from fused odontodes, and elongate, narrow lateral odontodes (Fig. 10G). The boundaries of the odontodes in some parts of the crown are poorly distinguished. Such scales were described from a fragment of squamation in Protacrodus vetustus Jaekel, 1925 (Gross 1938). The second morphotype of scales (Fig. $10 \mathrm{H})$ possesses a crown with a compact odontocomplex containing a central primordial odontode and surrounded by additional odontodes with distinct boundaries. Similar scales were described as Holmesella (Ørvig 1967) or orodontid scales (Ivanov \& Nilov 2017).

Besides the scales, the assemblage contains two spinelike denticles (Fig. 10I). These denticles have a monocuspid crown with a long, laterally compressed cusp covered by strong ridges. The latter are extended at the anterior edge where the ridges are bifurcated. The base is flat on the basal side, larger than the crown, extended anteriorly and narrowed posteriorly.

\section{Other fish remains}

Apart from chondrichthyans, the assemblage from the Horquilla Formation of the Robledo Mountains contains rare remains of other fishes such as acanthodian scales and actinopterygian teeth and scales. The four acanthodian scales possess the flat, smooth, rhomboid-shaped crown, narrow neck and convex, rounded base (Fig. 10J). This type of scale belongs to the "Acanthodes" type, and is characteristic of all representatives of the order Acanthodiformes.

The actinopterygian teeth include three morphotypes. The common morphotype is high-conical, straight, smooth teeth that are circular in cross-section, with a pointed acrodin cap (Fig. 10L). The second morphotype is low teeth with a wide rounded acrodin cap (Fig. 10K). The teeth of the third type (Fig. 10M) possess an extended apex with a flat occlusal surface. This surface bears strong ridges diverging from the center. The rare fragment of actinopterygian bone (Fig. 10N) and incomplete scales (Fig. 10O) are poorly preserved, and covered by ganoine ridges of different width and length. Some scales resemble the scales of elonichthyiforms.

\section{Biostratigraphic distribution}

Most of the chondrichthyan taxa found in the Robledo assemblage are widely distributed in the Carboniferous 


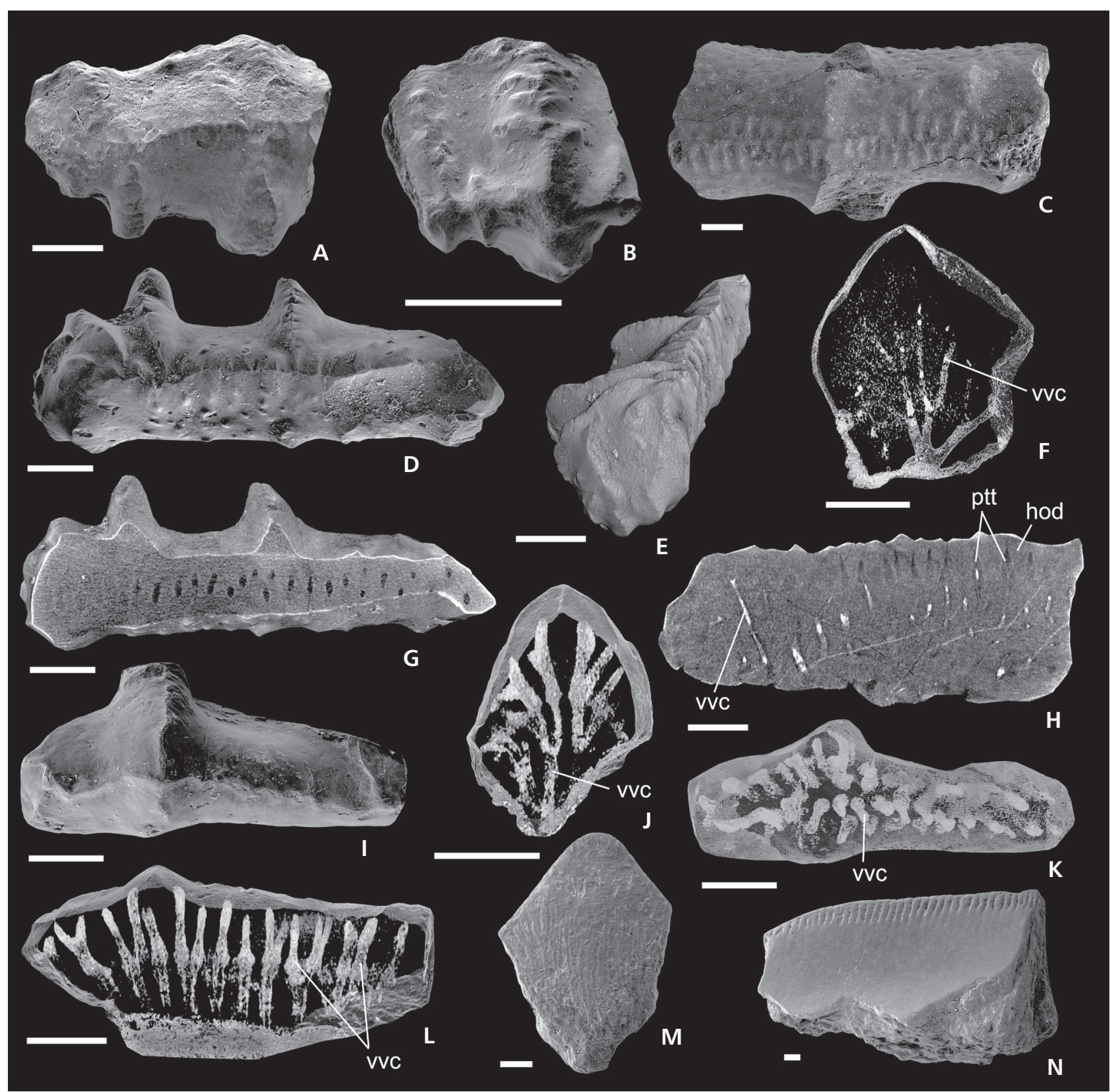

Figure 9. Euchondrocephalian teeth; Robledo Mountains, New Mexico, USA; Horquilla Formation, Missourian, Upper Pennsylvanian (A-D, I, M, $\mathrm{N}$ - scanning electron micrographs; E-H, J-L - micro-CT images). $• \mathrm{~A}-\mathrm{H}-$ Agassizodus sp., incomplete tooth crowns, occlusal views; A - NMMNH P-72321; B - NMMNH P-72322; C - NMMNH P-72323; D-H - NMMNH P-72324, occlusal (D) and oblique lateral (E) views, transverse (F in transparent mode), frontal $(\mathrm{G})$ and sagittal $(\mathrm{H})$ virtual sections. - I-L - Eugeneodontiformes indet., NMMNH P-72325, occlusal (I) view, transverse ( $\mathrm{J}$ in transparent mode), frontal $(\mathrm{K})$ and sagittal ( $\mathrm{L}$ in transparent mode) virtual sections. $\cdot \mathrm{M}, \mathrm{N}$ - Petalodontiformes indet., fragments of teeth, possibly labial views; M - NMMNH P-72326; N - NMMNH P-72327. Scale bars $=0.5 \mathrm{~mm}$. Abbreviations: hod - hypermineralized orthodentine; ptt - peritubular trabeculine; vvc - vertical vascular canal.

and Permian of many regions of the world and have long stratigraphic ranges.

The species of the xenacanthimorph Bransonella are recorded in the lower Carboniferous-middle Permian. B. lingulata Ivanov \& Ginter, 1996 has been found in the lower Viséan of the Kuznetsk Basin, Russia; the lower Serpukhovian of the Moscow Region, Russia (Hampe \&
Ivanov 2007); the lower Bashkirian of the South Urals, Russia (Ivanov \& Hampe 2015); and the Middle to Upper Pennsylvanian of Oklahoma, USA (Ivanov et al. 2017). Possible finds were described from the Bashkirian (Lower Pennsylvanian) of Arizona, USA (Johnson \& Thayer 2009). Bransonella nebraskensis (Johnson, 1984) occurs in the Viséan of the Nearpolar and South Urals, 
the Kaluga Region and the Kuznetsk Basin (Russia), the Holy Cross Mountains (Poland), England and the Dinantian Synclinorium (Belgium); in the Serpukhovian of Arizona (USA); in the lower Bashkirian and lower Moscovian of the South Urals (Russia); in the upper Moscovian of the Moscow Region (Russia); in the Gzhelian (Upper Pennsylvanian) of Nebraska and Kansas (USA); and the Sakmarian (lower Permian) of Kansas (USA) (Johnson 1984, Hampe \& Ivanov 2007, Ginter et al. 2015, Ivanov \& Hampe 2015, Hodnett \& Elliott 2018). Possible occurrences of this species are recorded from the Tournaisian of England (Behan et al. 2012) and Iran (Habibi \& Ginter 2011); and from the Bashkirian (Lower Pennsylvanian) of Arizona, USA (Johnson \& Thayer 2009). Recently, Bransonella spp. was reported from the Moscovian of eastern North Greenland (Cuny \& Stemmerik 2018).

The symmoriiform Stethacanthus is widely known from the Famennian (Upper Devonian) to the Kazanian (middle Permian) in many regions (Ginter et al. 2010, Ivanov \& Lebedev 2014). The symmoriiform Denaea is widely distributed in the Carboniferous. $D$. fournieri Pruvost, 1922 is known from the Visean of Belgium; D. saltsmani Ginter \& Hansen, 2010 occurs in the Pennsylvanian (Bashkirian-Gzhelian) of the USA (Ginter et al. 2010). Denaea wangi Wang, Jin \& Wang, 2004 is found in the Visean-Serpukhovian of Belgium, Germany, Poland and China (Wang et al. 2004, Ivanov \& Derycke 2005, Ginter et al. 2010). Denaea williamsi Ginter \& Hansen, 2010 is reported from the Visean-Serpukhovian, lower Carboniferous of Illinois and Arizona, USA, England, Scotland, Poland and the Moscow Region, Russia (Ginter et al. 2010, Hodnett \& Elliott 2018). Recently Denaea sp. was documented from the Moscovian, Pennsylvanian of eastern North Greenland (Cuny \& Stemmerik 2018).

The ctenacanthiform Glikmanius occidentalis (Leidy, 1859) has been reported from the Pennsylvanian- lower Permian of the USA (New Mexico, Arizona, Kansas, Indiana, Illinois, Ohio, Colorado and Texas); the Moscovian, Pennsylvanian-Kazanian, middle Permian of the East European Platform and the Urals, Russia; the middle Permian of Japan (Ginter et al. 2005, Johnson 2008); and the upper Leonardian, Permian of Arizona, USA (Hodnett et al. 2012). Glikmanius myachkovensis (Lebedev, 2001) occurs in the upper Carboniferous of the Moscow Syneclise, Donetsk Basin, and Nebraska (Ginter et al. 2005); the upper Leonardian, Permian of Arizona, USA (Hodnett et al. 2012); and probably the Wordian, middle Permian of Oman (Koot et al. 2013).

The euselachian Protacrodus is known from the Middle Devonian-Mississippian (Ginter et al. 2010). But, some protacrodontid teeth were found in the Pennsylvanian. For example, P. sibiricus Lebedev, 2001 was described from the Moscovian of the Ryazan and Moscow regions, Russia (Lebedev 2001).

The species of the neoselachian genus Cooleyella occur from the early Carboniferous to the middle Permian (Ivanov 2011). Cooleyella amazonensis Duffin, Richter $\&$ Neis, 1996 was reported from the Moscovian of Brazil; the Upper Pennsylvanian of New Mexico, Oklahoma and Kansas, (USA); the Artinskian of the South Urals (Russia); the Roadian of Texas (USA); and the Kazanian of the Tatarstan, Vladimir and Kirov regions (Russia) (Robb 1992, Duffin et al. 1996, Ivanov 2011, Ivanov \& Lucas 2014, Ivanov et al. 2012, Ivanov 2016). Cooleyella fordi (Duffin \& Ward, 1983) occurs in the Viséan-Serpukhovian, lower Carboniferous of the Nearpolar Urals, Moscow and Novgorod regions (Russia), Belgium and England; in the Serpukhovian of Arizona (USA) (Hodnett \& Elliott 2018); in the Moscovian, upper Carboniferous of North Timan (Russia); in the Gzhelian, Upper Pennsylvanian of Ohio (USA); in the Sakmarian-Artinskian, lower Permian of the South Urals (Ivanov 2011); and possibly in the middle Permian of Oman (Koot et al. 2013).

The jalodontid Adamantina foliacea Ivanov, 1999 has been recorded in the Tournaisian to the Roadian (Guadalupian, Permian): the Tournaisian of the South Urals, the Asselian of the Polar Urals, the Artinskian of the Middle Urals, Russia, the Moscovian of eastern North Greenland; the Upper Pennsylvanian of Iowa, USA; the Roadian of the Guadalupe Mountains, West Texas, USA (Ivanov 1999, Ivanov et al. 2012, Cuny \& Stemmerik 2018).

The species of the euchondrocephalian Orodus are known from the Middle Devonian to Pennsylvanian (Moscovian) of different regions (Ginter et al. 2010). Helodus is common from the Upper Devonian to lower Permian of Australia, Eurasia and North America (Stahl 1999). The eugeneodontiform Agassizodus occurs in the Upper Pennsylvanian of the USA (Ginter et al. 2010).

The ranges for most fish taxa from the Robledo assemblage do not contradict the conodont data that indicate a Missourian (Kasimovian) age (see above). Only the protacrodontids and orodontids were not yet known from the Upper Pennsylvanian, and these are globally their youngest records.

\section{New finds of Paleozoic chondrichthyans in New Mexico}

Here, we briefly document some new finds of Paleozoic chondrichthyans in New Mexico apart the fish assemblage from the Robledo Mountains, that were not included in the last reviews of Paleozoic fish occurrences in New Mexico (Hodnett \& Lucas 2015, 2017). The age of the fish assemblage from the Sly Gap Formation is also discussed here. 


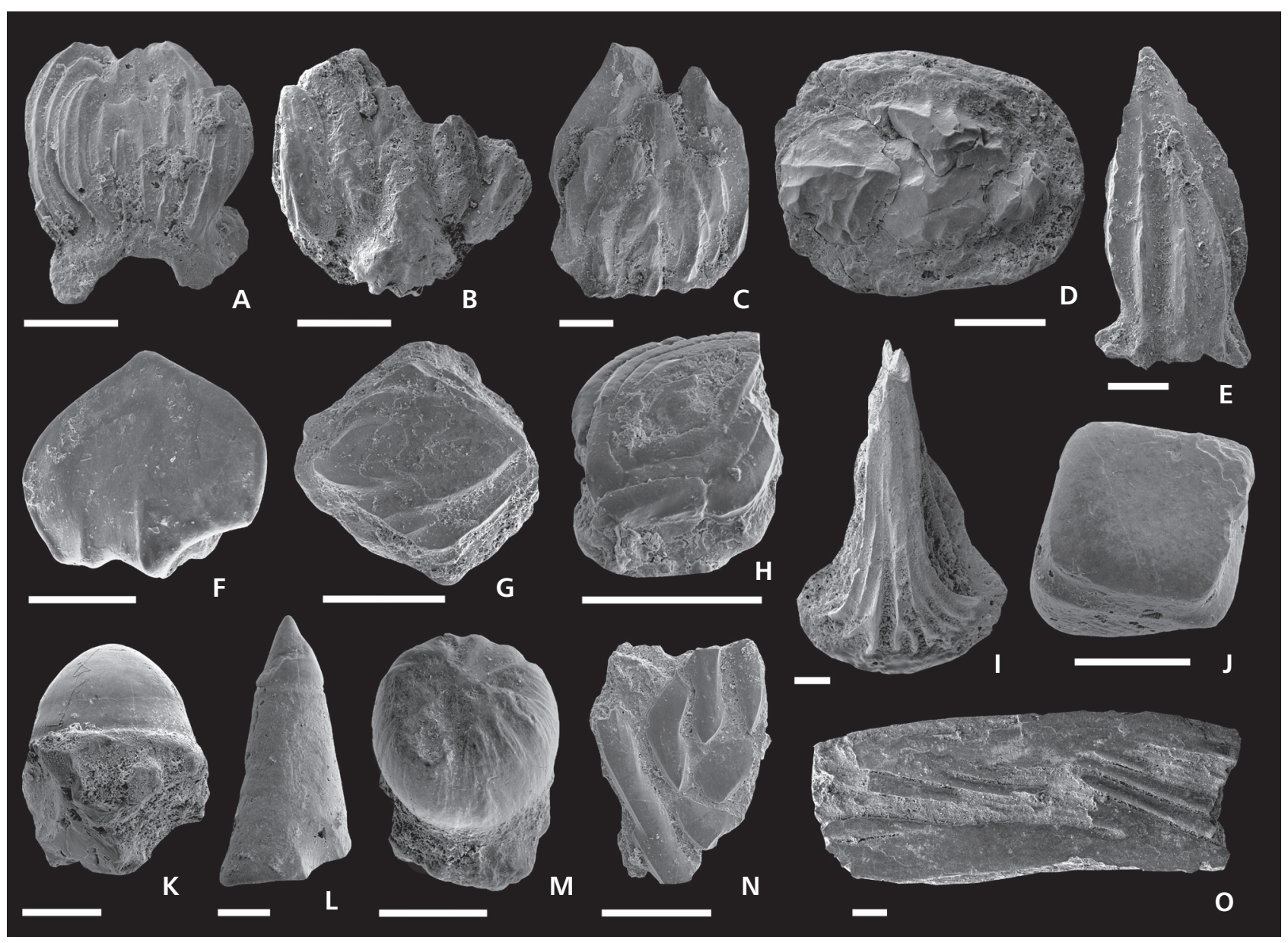

Figure 10. Fish microremains; Robledo Mountains, New Mexico, USA; Horquilla Formation, Missourian, Upper Pennsylvanian. • A-I chondrichthyan scales; A-C - ctenacanthid type scales, crown views, NMMNH P-72328 (A), NMMNH P-72329 (B), NMMNH P-72330 (C). - D - tessera-like scale, NMMNH P-72331, crown view. • E, F - euselachian scales, anterior views; E - NMMNH P-72332, F - NMMNH P-72333. G, H - protacrodontid type scale; G - NMMNH P-72334, crown view; H - NMMNH P-72335, oblique crown view. $\bullet$ I - spine-like denticle, NMMNH P-72336, crown view. $・ \mathrm{~J}$ - acanthodiform scale, NMMNH P-72337, crown view. $・ \mathrm{~K}-\mathrm{O}$ - actinopterygian microremains; K-M - teeth, NMMNH P-72338 (K) lateral view, NMMNH P-72339 (L), lateral view, NMMNH P-72340 (M) oblique occlusal view; N - fragment of bone, NMMNH P-72342, external view; O - scale, NMMNH P-72341, external view. Scale bars $=0.2 \mathrm{~mm}$.

\section{Devonian}

The fin spine fragment of Ctenacanthus cf. venustus Eastman, 1902 (Fig. 11A-D) was found in the Box Mermber of the Percha Formation (Late Devonian) at the Percha type section (NMMNH locality 6945) in south-central New Mexico. This incomplete distal part of a fin spine is compressed laterally, incurved, with slightly convex lateral, narrow anterior and prominent posterior surfaces. The cross section is semioval, with a large central cavity (Fig. 11D). The ornamentation consists of longitudinal ridges separated by narrow grooves. The ridges bear the elongated tubercles oriented at different angles to the ridge axis (Fig. 11C). The tubercles are slightly striated and placed at different distances from each other. The tubercles form the slightly incurved transverse ridges at the anterior edge (Fig. 11A). The posterior surface bears a prominent ridge separated by deep grooves from the posterior edges. The posterior denticles are not preserved. This incomplete fin spine differs from the fin spines of Ctenacanthus venustus Eastman, 1902 in the more rare location of tubercles on the longitudinal ridges (Maisey 1981).

Hodnett \& Lucas (2015) observed that the fish assemblage from the Sly Gap Formation included the mixed taxa from the Devonian and Carboniferous and suggested that the age of the assemblage is Devonian, but the taxa earlier known only from the Carboniferous first appeared in New Mexico in the Devonian. This suggestion is not confirmed by the co-occurrence of Frasnian Phoebodus latus Ginter \& Ivanov, 1995 and Famennian P. gothicus Ginter, 1990. Phoebodus latus and other Frasnian phoebodontids disappeared after the end-Frasnian mass extinction and did not exist in the Famennian interval of the crepidapraesulcata conodont zones when $P$. gothicus existed 


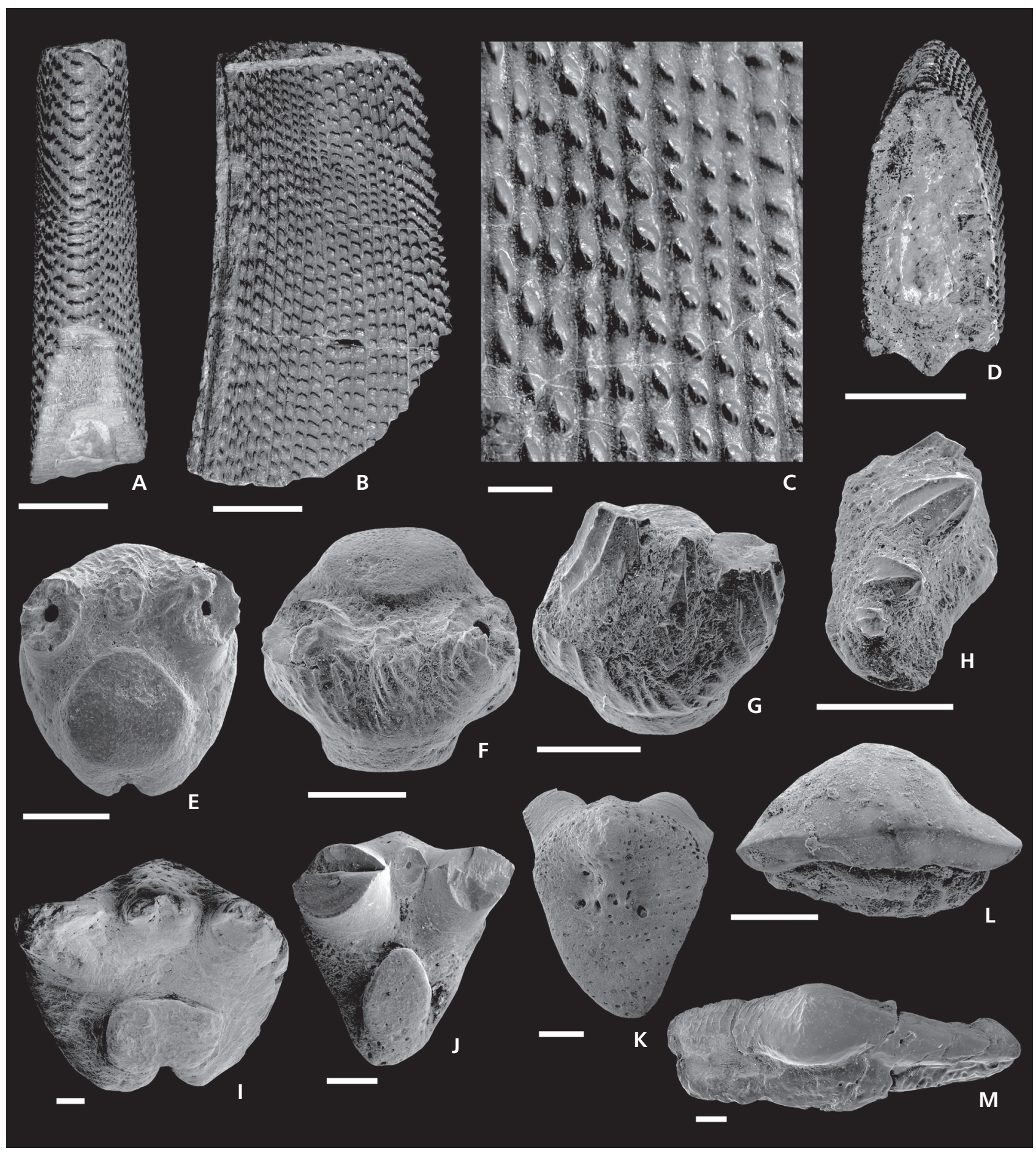

Figure 11. Some Paleozoic chondrichthyans of New Mexico, USA. • A-D - Ctenacanthus cf. venustus Eastman, 1902, incomplete fin spine, NMMNH P-54783; Percha type section, locality NMMNH 6945; Box Member, Percha Formation, Upper Devonian; A - anterior; B - right lateral views; C - detail of ornamentation; D - section of distal part. $\bullet$ E-G - Bransonella lingulata Ivanov \& Ginter, 1996, teeth; Talpa, locality NMMNH 1382, Taos Canyon; Flechado Formation, Desmoinesian, Middle Pennsylvanian; E, F - NMMNH P-14165a, occlusal (E) and oblique labial (F) views; G - NMMNH P-14165b, labial view. • H - Sphenacanthus sp., tooth, NMMNH P-12093, oblique lateral view; same locality and age. • I - Orthacanthus sp., tooth, NMMNH P-31823a, occlusal view; locality NMMNH 3390, Sandoval County; Atrasado Formation, Virgilian, Upper Pennsylvanian. $・ J, K$ - Orthacanthus cf. texensis (Cope, 1888), teeth, locality NMMNH 4706, Rio Arriba County; El Cobre Canyon Formation, Cutler Group, Wolfcampian, lower Permian; J - NMMNH P-34787a, occlusal view; K - NMMNH P-34787b, basal view. • L - "Lissodus" sp., tooth, NMMNH P-50544c, occlusal view; locality NMMNH 6826, East of Soccoro; Busrum Formation, Wolfcampian, lower Permian. • M "Polyacrodus" sp., tooth, NMMNH P-32058, oblique occlusal view; locality NMMNH 3423, Valencia; Red Tanks Member, Bursum Formation, Virgilian (Upper Pennsylvanian) -Wolfcampian (lower Permian). Scale bars: A, B, D = $10 \mathrm{~mm} ; \mathrm{C}=2 \mathrm{~mm} ; \mathrm{E}-\mathrm{H}=0.5 \mathrm{~mm}$; $\mathrm{I}-\mathrm{M}=1 \mathrm{~mm}$. 
(Ginter \& Ivanov 1995). Thus, the age of assemblages is more believably Mississippian with reworked remains from the Frasnian and Famennian as discussed earlier (Ivanov \& Lucas 2011).

\section{Middle Pennsylvanian}

Teeth of Bransonella lingulata Ivanov \& Ginter, 1996 and the tooth of Sphenacanthus sp. occur in the Flechado Formation (Desmoinesian) of Talpa (NMMNH locality 1382), Taos Canyon, northern New Mexico. The teeth of B. lingulata (Fig. 11E-G) are typical bransonellid teeth with a diplodont crown covered by the inverted "V"nested ornamentation on the labial side, and with an oval tooth base bearing a prominent, oval apical button and semilunar labio-basal tubercle. Together with the Robledo fish fauna, this is the second record of $B$. lingulata in the Paleozoic in New Mexico.

The incomplete tooth of Sphenacanthus sp. (Fig. 11H) possesses the pyramidal protacrodont crown slightly inclined lingually. The cusps are rounded in cross section, gradually arranged by their height, and fused basally. The coarse, straight cristae cover all cusps, diverging from the cusp apex. The tooth base is slightly extended lingually, with prominent occlusal and flat basal surfaces. This tooth was illustrated by Kietzke (1990) for the first time as ichthyolith type A. Later, Zidek \& Kietzke (1993) attributed this specimen to Limnoselache. But, this tooth closely resembles the teeth of Sphenacanthus carbonarius (Giebel, 1848) and S. serrulatus Agassiz, 1837 (SolerGijon 1997, Dick 1998).

\section{Upper Pennsylvanian-lower Permian}

Teeth of Orthacanthus were found in the Atrasado Formation (Virgilian, Upper Pennsylvanian) of Sandoval County, NMMNH locality 3390, and in the El Cobre Canyon Formation of the Cutler Group (Wolfcampian, lower Permian) of Rio Arriba County, NMMNH locality 4706. The Orthacanthus teeth from the Atrasado Formation have a wide crown and base, two small central cusps, an almost rectangular apical button and a prominent basal tubercle (Fig. 11I). They are slightly similar to some teeth of O. gibbosus (Binney, 1840) and O. platypternus (Cope, 1884) (Hampe 2003, Johnson 2018). The teeth from the El Cobre Canyon Formation are attributed to $O$. cf. texensis (Cope, 1888) and possess large lateral cusps compressed linguo-labially, with serrated lateral carinae (Fig. 11J, K). The tooth base is elongated lingually and bears an oval apical button and a narrow basal tubercles.

A tooth of "Polyacrodus" sp. occurs in the Red Tanks Member, Bursum Formation (Virgilian, Upper Pennsyl-
vanian-Wolfcampian, lower Permian) of Valencia County, central New Mexico (NMMNH locality 3423). This tooth has an elongate, pyramidal crown with an extended central part and anostomosing cristae (Fig. 11M). The tooth is similar to the teeth of $P$. ritchiei Johnson, 1981 and ?Acrodus sweetlacruzensis Johnson, 1981 (Johnson 1981), although it is somewhat larger.

The fish assemblage from the early Permian (Wolfcampian) Bursum Formation NMMNH locality 6826 east of Soccoro in central New Mexico includes the teeth of Glikmanius sp., "Lissodus" sp. and "Polyacrodus" sp. Most of the teeth are poorly preserved. The teeth of "Lissodus" (Fig. 11L) resemble the teeth of "L." zideki (Johnson, 1981) from the lower Permian of Texas (Johnson 1981). The teeth of "Polyacrodus" are similar to the polyacrodontid teeth described from the upper Permian of Iran (Hampe et al. 2013).

\section{Conclusions}

The fish assemblage from the Horquilla Formation of the Robledo Mountains, including numerous chondrichthyans, rare acanthodians and actinopterygians, is one of the most taxonomically diverse assemblages of Paleozoic fish in New Mexico. It contains chondrichthyan taxa such as Bransonella, Adamantina, Cooleyella, which, for the first time are reported from New Mexico. The occurrences of protacrodontids and orodontids in the Missourian are their youngest records.

Besides the Robledo fish fauna, the new discoveries of Paleozoic chondrichthyans augment the taxonomic diversity in the fish assemblages. Ctenacanthus is recorded for the first time in the Late Devonian of New Mexico, and the records of Bransonella and Sphenacanthus are their first occurrences in the Middle Pennsylvanian of New Mexico.

\section{Acknowledgments}

The authors are grateful to Gary Johnson (Southern Methodist University, Dallas) and Wayne Itano (University of Colorado, Boulder) for useful discussions, to Roman Rakitov (Borissiak Paleontological Institute of the Russian Academy of Sciences, Moscow), to Natalya Vlasenko and Vladimir Shilovskikh (Research park of the St. Petersburg State University) for assistance during SEM imaging, to Sergey Nilov (Institute of the Earth Sciences, St. Petersburg State University) for the microtomographic sections and reconstruction, and to Karl Krainer and Sebastian Voigt for collaboration in the field. James Barrick generously processed the samples from the Horquilla Formation from which the fossils described here were extracted. The work is performed according to the Russian Government Program of Competitive Growth of Kazan Federal University. The study was supported by a grant from the Saint-Petersburg 
State University No. 3.42.730.2017 and by RFBR, research project No. 14-04-01507a. Scientific researches were performed at the Center for Geo-Environmental Research and Modeling (GEOMODEL) and the Centre for X-ray Diffraction Studies of Research Park of St. Petersburg State University. We thank Gary Johnson (Southern Methodist University, Dallas) and an anonymous reviewer for useful comments.

\section{References}

Agassiz, L. 1833-43. Recherches sur les Poissons fossils. 5 vols + supplement. 1420 pp. Petitpierre, Neuchâtel.

Barrick, J.E., Lambert, L.L., Heckel, P.H., Rosscoe, S.J. \& Boardman, D.R. 2013. Midcontinent Pennsylvanian conodont zonation. Stratigraphy 10, 55-72.

Behan, C., Walken, G. \& Cuny, G. 2012. A Carboniferous chondrichthyan assemblage from residues within a Triassic karst system at Cromhall Quarry, Gloucestershire, England. Palaeontology 55(6), 1245-1263.

DOI 10.1111/j.1475-4983.2012.01193.x

BendiX-Almgreen, S.E. 1993. Adamantina benedictae n. g. et sp.en nyhed fra Østgronlands marine Ovre Perm, 48-58. In JoHnsen, O. (ed.) Geologisk Museum - 100 år på Østervold. Rodos, København.

Binney, E.W. 1840. On the fossil fishes of the Pendleton Coal Field. Transactions of the Geological Society of Manchester 1840, 153-178.

Bonaparte, C.L.J. 1832-1841. Iconografia della Fauna Italica, per le quattro classi degli animali vertebrati. Tomo 3: Pesci. 266 pp. Dalla Tipografia Salviucci, Rome.

Bonaparte, C.L.J. 1838. Selachorum tabula analytica. Nuovi Annali delle Scienze Naturali Bologna 1, 195-214.

Burrow, C.J., Long, J.A. \& Trinajstic, K. 2009. Disarticulated acanthodian and chondrichthyan remains from the upper Middle Devonian Aztec Siltstone, southern Victoria Land, Antarctica. Antarctic Science 21, 71-88.

DOI 10.1017/S0954102008001521

Cappetta, H., Duffin, C. \& Zidek, J. 1993. Chondrichthyes, 593609. In Benton, M.J. (ed.) The Fossil Record 2. Chapman and Hall, London.

Coates, M.I. \& Sequeira, S.E.K. 2001. A new stethacanthid chondrichthyan from the Lower Carboniferous of Bearsden, Scotland. Journal of Vertebrate Paleontology 21, 438-459. DOI 10.1671/0272-4634(2001)021[0438:ANSCFT]2.0.CO;2

Compagno, L.J.V. 1977. Phyletic relationships of living sharks and rays. American Zoologist 17, 303-322. DOI 10.1093/icb/17.2.303

Cope, E.D. 1884. On the structure of the skull in the elasmobranch genus Didymodus. Proceedings of the American Philosophical Society 21, 572-590.

Cope, E.D. 1888. Systematic catalogue of the species of Vertebrata found in the beds of the Permian epoch in North America, with notes and descriptions. Transactions of the American Philosophical Society 26, 285-297.

DOI 10.2307/1005392
Cuny, G. \& Stemmerik, L. 2018. New fossil fish microremains from the Upper Carboniferous of eastern North Greenland. Bulletin of the Geological Society of Denmark 66, 47-60.

Dean, B. 1909. Studies on fossil fishes (sharks, chimaeroids and arthrodires). Memoirs of the American Museum of Natural History Part V, 9, 211-287.

Dick, J.R.F. 1998. Sphenacanthus, a Palaeozoic freshwater shark, 9-25. In Norman, D.B., Milner, A.R. \& Milner, A.C. (eds) A Study of Fossil Vertebrates. Zoological Journal of the Linnean Society 122.

Duffin, C.J. \& WARD, D.J. 1983. Neoselachian shark teeth from the Lower Carboniferous of Britain and the Lower Permian of the USA. Palaeontology 26(1), 93-110.

Duffin, C.J., Richter, M. \& NeIs, P.A. 1996. Shark remains from the Late Carboniferous of the Amazon Basin, Brazil. Neues Jahrbuch für Geologie und Paläontologie 4, 232-256.

Duncan, M. 2004. Chondrichthyan genus Lissodus from the Lower Carboniferous of Ireland. Acta Palaeontologica Polonica 49(3), 417-428.

Eastman, C.R. 1902. Some Carboniferous cestraciont and acanthodian sharks. Bulletin of the Museum of Comparative Zoology 39(3), 55-99.

Giebel, C.G. 1848. Fauna der Vorwelt mit steter Berücksichtigung der lebenden Thiere, Bd. 1: Wirbelthiere, Abt. 3: Fische. 467 pp. Brockhaus, Leipzig.

GinTER, M. 1990. Late Famennian shark teeth from the Holy Cross Mts, Central Poland. Acta Geologica Polonica 40, 69-81.

Ginter, M. \& Hansen, M. 2010. Teeth of the cladodont shark Denaea from the Carboniferous of central North America, 29-44. In: NowaKowski, D. (ed.) Morphology and Systematics of Fossil Vertebrates. DN Publisher, Wroclaw.

Ginter, M. \& Ivanov, A. 1995. Middle/Late Devonian phoebodont-based ichthyolith zonation. Géobios, Mémoire Special 19, 351-355. DOI 10.1016/S0016-6995(95)80137-5

Ginter, M., Hairapetian, V. \& Klug, C. 2002. Famennian chondrichthyans from the shelves of North Gondwana. Acta Geologica Polonica 52, 169-215.

Ginter, M., Hampe, O. \& Duffin, C.J. 2010. Chondrichthyes Paleozoic Elasmobranchii: Teeth, 1-168. In Schultze, H.-P. (ed.) Handbook of Paleoichthyology, 3D. Verlag Dr. Friedrich Pfeil, Munich.

Ginter, M., Ivanov, A. \& Lebedev, O. 2005. The revision of "Cladodus" occidentalis, a late Palaeozoic ctenacanthiform shark. Acta Palaeontologica Polonica 50, 623-631.

Ginter, M., Duffin, C.J., Dean, M.T. \& Korn, D. 2015. Late Viséan pelagic chondrichthyans from northern Europe. Acta Palaeontologica Polonica 60(4), 899-922.

Glikman, L.S. 1964. Subclass Elasmobranchii. Sharks, 196-237. In Obruchev, D.V. (ed.) Fundamentals of Paleontology. Agnathans, Fishes. Nauka, Moscow. [in Russian]

Grogan, E.D. \& Lund, R. 2000. Debeerius ellefseni (Fam. Nov., Gen. Nov., Spec. Nov.), an autodiastylic chondrichthyan from the Mississippian Bear Gulch Limestone of Montana (USA), the relationships of the Chondrichthyes, and comments on gnathostome evolution. Journal of Morphology 243, 219-245. DOI 10.1002/(SICI) 1097-4687(200003)243:3<219:: AID-JMOR1>3.0.CO;2-1 
Gross, W. 1938. Das Kopfskelett von Cladodus wildungensis Jaekel. 2. Teil: Der Kieferbogen. Anhang: Protacrodus vetustus Jaekel. Senckenbergiana 20, 123-145.

Gunnell, F.M. 1933. Conodonts and fish remains from the Cherokee, Kansas City, and Wabaunsee groups of Missouri and Kansas. Journal of Paleontology 7, 261-297.

Habibi, T. \& Ginter, M. 2011. Early Carboniferous chondrichthyans from the Mobarak Formation, centralAlborz Mountains, Iran. Acta Geologica Polonica 61, 27-34.

Hampe, O. 2003. Revision of the Xenacanthida (Chondrichthyes: Elasmobranchii) from the Carboniferous of the British Isles. Transactions of the Royal Society of Edinburgh: Earth Sciences 93(3), 191-237. DOI $10.1017 / \mathrm{S} 0263593300000419$

Hampe, O. \& Ivanov, A. 2007. Bransonelliformes - a new order of the Xenacanthimorpha (Chondrichthyes: Elasmobranchii). Fossil Records 10(2), 190-194. DOI 10.5194/fr-10-190-2007

Hampe, O., Hairapetian, V., Dorka, M., Witzmann, F., Akbari, A.M. \& Korn, D. 2013. A first Late Permian fish fauna from Baghuk Mountain (Neo-Tethyan shelf, central Iran). Bulletin of Geosciences 88(1), 1-20.

Harlton, B.H. 1933. Micropaleontology of the Pennsylvanian Johns Valley shale of the Ouachita Mountains, Oklahoma, and its relationship to the Mississippian Caney shale. Journal of Paleontology 7(1), 3-29.

HAY, O.P. 1902. Bibliography and catalogue of the fossil Vertebrata of North America. U.S. Geological Survey Bulletin 179, 1-868.

HAY, O.P. 1929. Second bibliography and catalogue of the fossil Vertebrata of North America. Carnegie Institution of Washington Publication 390(1), 1-916.

Hodnett, J.-P.M. \& Elliott, D.K. 2018. Carboniferous chondrichthyan assemblages from the Surprise Canyon and Watahomigi formations (latest Mississippian-Early Pennsylvanian) of the western Grand Canyon, Northern Arizona. Journal of Paleontology 92, Memoir 77, 1-33. DOI 10.1017/jpa.2018.72

Hodnett, J-P.M. \& Lucas, S.G. 2015. Paleozoic fishes of New Mexico: A review. New Mexico Museum of Natural History and Science, Bulletin 68, 51-63.

Hodnett, J.-P.M. \& Lucas, S.G. 2017. Paleoichthyological assemblages of the Upper Carboniferous-Lower Permian of Socorro County, New Mexico. New Mexico Museum of Natural History and Science, Bulletin 77, 133-138.

Hodnett, J-P.M., Elliott, D.K., Olson, T.J. \& WittKe, J.H. 2012. Ctenacanthiform sharks from the Permian Kaibab Formation, northern Arizona. Historical Biology 24, 381-395. DOI 10.1080/08912963.2012.683193

HuXLEY, T.H. 1880. On the application of the laws of evolution to the arrangement of the Vertebrata, and more particularly of the Mammalia. Proceedings of the Zoological Society of London 1880, 649-662.

ItANo, W.M. \& LuCAS, S.G. 2018. A revision of Campyloprion Eastman, 1902 (Chondrichthyes, Helicoprionidae), including new occurrences from the Upper Pennsylvanian of New Mexico and Texas, USA. Acta Geologica Polonica 68(3), 403-419.
Ivanov, A. 1999. Late Devonian - Early Permian chondrichthyans of the Russian Arctic. Acta Geologica Polonica 49, 267-285.

Ivanov, A. 2011. Permian anachronistid sharks of the East European Platform and Urals, 17-19. In SHishrin, M.A., Golubev, V.K., Novikov, I.V. \& Sennikov, A.G. (eds) Palaeozoic and Mesozoic Vertebrates of Eurasia: Evolution, Assemblage Changes, Taphonomy and Palaeobiogeography. Proceedings of the International Conference. Palaeontological Institute Publ., Moscow. [in Russian]

Ivanov, A.O. 2016. Chondrichthyans from the Lower Permian of Mechetlino, South Urals, Russia. The Bulletin of Geosciences 92(4), 717-729.

Ivanov, A. \& Derycke, C. 2005. Viséan elasmobranchs of Belgium. Ichthyolith Issues, Special Publication 9, 13-17.

Ivanov, A. \& Ginter, M. 1996. Early Carboniferous xenacanthids (chondrichthyes) from eastern Europe. Bulletin de la Société géologique de France 167, 651-656.

IvANOv, A.O. \& HAMPE, O. 2015. Occurrence of xenacanthimorph sharks in the Carboniferous of Russia, 86. In Nurgaliev, D.K. (ed.) Abstract volume of the XVIII International Congress on the Carboniferous and Permian. Kazan Federal University, Kazan.

Ivanov, A.O. \& Lebedev, O.A. 2014. Permian chondrichthyans of the Kanin Peninsula, Russia. Paleontological Journal 48(9), 1030-1043. DOI 10.1134/S0031030114090056

Ivanov, A. \& Lucas, S.G. 2011. Fish fossils from the Paleozoic Sly Gap Formation of southern New Mexico, USA. New Mexico Museum of Natural History and Science, Bulletin 53, $52-70$.

Ivanov, A.O. \& LucAs, S.G. 2014. Fish assemblage from the Late Pennsylvanian of the Robledo Mountains, New Mexico. Geological Society of America, Abstracts with Programs 46(1), 2.

Ivanov, A.O. \& Nilov, S.P. 2017. Investigation of internal structure in the scales of Palaeozoic cartilaginous fishes using micro-CT. Abstracts of Micro-CT User Meeting, Brussels, $31-36$.

Ivanov, A., Lucas, S.G. \& Krainer, K. 2009. Pennsylvanian fishes from the Sandia Formation, Socorro County, New Mexico, 243-248. In Lueth, V.W., Lucas, S.G. \& Chamberlin, R.M. (eds) Geology of the Chupadera Mesa, Guidebook 60. New Mexico Geological Society, Socorro.

Ivanov, A., Nestell, M. \& Nestell, G. 2012. New jalodontid chondrichthyans from the Middle Permian of West Texas, USA. Historical Biology 24(4), 359-368. DOI 10.1080/08912963.2012.662229

Ivanov, A.O., Seuss, B. \& Nützel, A. 2017. The fish assemblage from the Pennsylvanian Buckhorn Asphalt Quarry Lagerstätte (Oklahoma, USA). Paläontologische Zeitschrift 91(4), 565-576. DOI 10.1007/s12542-017-0361-9

JAEKEL, O. 1925. Das Mundskelett der Wirbeltiere. Gegenbaurs Morphologishes Jahrbuch 55, 402-409.

Johnson, G.D. 1981. Hybodontoidei (Chondrichthyes) from the Wichita-Albany Group (Early Permian) of Texas. Journal of Vertebrate Paleontology 1, 1-41. DOI 10.1080/02724634.1981.10011876 
Johnson, G.D. 1984. A new species of Xenacanthodii (Chondrichthyes, Elasmobranchii) from the late Pennsylvanian of Nebraska. Carnegie Museum of Natural History Special Publication 9, 178-186.

Johnson, G.D. 2008. Ctenacanthiform cladodont teeth from the Lower Permian Wichita Group, Texas, U.S.A. Acta Geologica Polonica 58(2), 205-209.

JoHnson, G.D. 2018. Orthacanthus platypternus (Cope, 1883) (Chondrichthyes: Xenacanthiformes) teeth and other isolated vertebrate remains from a single horizon in the early Permian (Artinskian) Craddock Bonebed, lower Clear Fork Group, Baylor County, Texas, USA. Acta Geologica Polonica 68(3), 421-436.

Johnson, G.D. \& Thayer, D.W. 2009. Early Pennsylvanian xenacanth chondrichthyans from the Swisshelm Mountains, Arizona, USA. Acta Palaeontologica Polonica 54(4), 649-668. DOI 10.4202/app.2008.0051

KietzKe, K.K. 1990. Microfossils from the Flechado Formation (Pennsylvanian, Desmoinesian) near Talpa, New Mexico, 259-276. In Bauer, P.W., Lucas, S.G., Mawer, C.K. \& McIntosh, W.C. (eds) Tectonic development of the southern Sangre de Cristo Mountains, New Mexico, Guidebook 41. New Mexico Geological Society, Socorro.

KonincK, L.-G. De 1878. Faune du calcaire carbonifère de la Belgique. Première partie, poissons et genre nautile. Annales du Musée royal d'Histoire naturelle de Belgique 2, 1-152.

Koot, M.B., Cuny, G., Tintori, A. \& Twitchett, J.J. 2013. A new diverse shark fauna from the Wordian (Middle Permian) Khuff Formation in the interior Haushi-Huqf area, Sultanate of Oman. Palaeontology 56(2), 303-343. DOI 10.1111/j.1475-4983.2012.01199.x

Krainer, K., Lucas, S.G., Vachard, D. \& Barrick, J.E. 2015. The Pennsylvanian-Permian section at Robledo Mountain, Doña Ana County, New Mexico, USA. New Mexico Museum of Natural History and Science, Bulletin 65, 9-41.

Lebedev, O.A. 2001. Pozvonochnye [Vertebrates], 196-201. In Alekseev, A.S. \& Shik, S.M. (eds) Srednij karbon Moskovskoy sineklizy (yuzhnaya chast') 2, Paleontologicheskaya kharakteristika. Nauchniy mir, Moscow. [in Russian]

LeIDY, J. 1859. Descriptions of Xystracanthus arcuatus and Cladodus occidentalis. Proceedings of the Academy of Natural Sciences of Philadelphia 1859, 3.

Lucas, S.G. \& EsteP, J.W. 2000. Pennsylvanian selachians from the Cerros de Amado, central New Mexico. New Mexico Museum of Natural History and Science, Bulletin 16, 21-28.

Lucas, S.G., Krainer, K. \& Vachard, D. 2015. The lower Permian Hueco Group, Robledo Mountains, New Mexico. New Mexico Museum of Natural History and Science, Bulletin 65, 43-95.

Lucas, S.G., Spielmann, J.A., Ivanov, A.O., Rinehart, L.F. \& Krainer, K. 2011. Petalodont chondrichthyan teeth from the Pennsylvanian-Permian Horquilla Formation, Big Hatchet Mountains, New Mexico. New Mexico Museum of Natural History and Science, Bulletin 53, 110-114.

Lund, R. \& Grogan, E.D. 1997. Relationships of the Chimaeriformes and the basal radiation of the Chondrichthyes. Review Fisheries Biology Fisheries 7, 65-123.

DOI 10.1023/A:1018471324332
Maisey, J.G. 1975. The interrelationships of phalacanthous selachians. Neues Jahrbuch für Geologie und Paläontologie, Monatshefte 1975, 553-567.

Maisey, J.G. 1981. Studies on the Paleozoic selachian genus Ctenacanthus Agassiz No. 1. Historical review and revised diagnosis of Ctenacanthus, with a list of referred taxa. American Museum Novitates 2718, 1-22.

Maisey, J.G. 2010. Heslerodidae (Chondrichthyes, Elasmobranchii), a new family of Paleozoic phalacanthous sharks. Kirtlandia 37, 13-21.

Nelson, J.S. 1976. Fishes of the world. 416 pp. Wiley \& Sons, New York.

Newberry, J.S. 1889. The Paleozoic fishes of North America. U.S. Geological Survey Monograph 16, 1-340.

Newberry, J.S. \& Worthen, A.H. 1866. Descriptions of vertebrates. Geological Survey of Illinois 2, 9-134.

Obruchev, D.V. 1953. Edestid Studies and the Works of A.P. Karpinsky. Trudy Paleontologiceskogo Instituta Akademija Nauk SSSR 45, 1-85. [in Russian]

ØRVIG, T. 1967. Histologic studies of ostracoderms, placoderms and fossil elasmobranchs. 2. On the dermal skeleton of two late Paleozoic elasmobranchs. Arkiv för Zoologi 19(1), 1-39.

Patterson, C. 1965. The phylogeny of the Chimaeroids. Philosophical Transactions Royal Society London B 249, 101-219. DOI 10.1098/rstb.1965.0010

Pruvost, P. 1922. Déscription de Denaea fournieri, sélacien nouveau du Marbre noir de Denée. Part 2 of Fournier, G. and Pruvost, P., Découverte d'un poisson nouveau dans le marbre noir de Denée. Bulletin de Academie Royal de Bruxelles Serie 5 , 8, 213-218.

Roвв III, A.J. 1992. Vertebrate fossils from the Lawrence Formation (Douglas Group, Virgilian, Upper Pennsylvanian) in Northeastern Kansas. Transactions of the Kansas Academy of Science 95(1/2), 129-138. DOI 10.2307/3628028

Roelofs, B., Barham, M., Mory, A.J. \& Trinajstic, K. 2016. Late Devonian and Early Carboniferous chondrichthyans from the Fairfield Group, Canning Basin, Western Australia. Palaeontologia Electronica 19.1.4A, http://palaeo-electronica.org, $1-28$.

Roelofs, B., Playton, T., Barham, M. \& Trinajstic, K. 2015. Upper Devonian microvertebrates from the Canning Basin, Western Australia. Acta Geologica Polonica 65, 69-101. DOI 10.1515/agp-2015-0003

Rosscoe, S.J. \& BArrick, J.E. 2013. North American species of the conodont genus Idiognathodus from the MoscovianKasimovian boundary composite sequences and correlation of the Moscovian-Kasimovian boundary. New Mexico Museum of Natural History and Science, Bulletin 60, 354-371.

Soler-Gijón, R. 1997. Euselachian sharks from the Late Carboniferous of the Puertollano basin, Spain: biostratigraphic and palaeoenvironmental implications. Modern Geology 21, 137-169.

ST. John, O.H. \& Worthen, A.H. 1875, Descriptions of fossil fishes. Geological Survey of Illinois 6, 245-488.

Stahl, B.J. 1999. Chondrichthyes III. Holocephali, 1-164. In Schultze, H.-P. (ed.) Handbook of Palaeoichthyology 4. Verlag Dr. Friedrich Pfeil, München. 
WANG, N-Z., JIN, F. \& WANG, W. 2004. Early Carboniferous fishes (acanthodian, actinopterygians and Chondrichthyes) from the east sector of north Qilian Mountain, China - Carboniferous fish sequence from the east sector of north Qilian Mountain. Vertebrata Palasiatica 42, 89-110.

Williams, M.E. 1985. The 'cladodont level' sharks of the Pennsylvanian black shales of central North America. Palaeontographica A 190(3/6), 83-158.

ZANGERL, R. 1981. Chondrichthyes I. Paleozoic Elasmobranchii, 1-115. In Schultze, H.-P. (ed.) Handbook of Paleoichthyology $3 A$. Fischer, Stuttgart.
ZANGERL, R. 1990. Two new stethacanthid sharks (Stethacanthidae, Symmoriida) from the Pennsylvanian of Indiana, U.S.A. Palaeontographica A 213, 115-141.

Zangerl, R. \& CAse, G.C. 1976. Cobelodus aculeatus (Cope), an anacanthous shark from Pennsylvanian black shales of North America. Palaeontographica A 154, 107-157.

ZideK, J. \& KieTZKe, K.E. 1993. Pre-Permian vertebrates of New Mexico, with remarks on some Early Permian specimens. New Mexico Museum of Natural History and Science, Bulletin 2, $1-10$. 